\title{
Green Synthesis of Metallic Nanoparticles: Applications and Limitations
}

\author{
Pritam Kumar Dikshit ${ }^{1, * \mathbb{D}}$, Jatin Kumar ${ }^{1}$, Amit K. Das ${ }^{1}$, Soumi Sadhu ${ }^{1}$, Sunita Sharma ${ }^{2}$, Swati Singh ${ }^{1}$, \\ Piyush Kumar Gupta ${ }^{1}$ (D) and Beom Soo Kim ${ }^{3, *(D)}$
}

1 Department of Life Sciences, School of Basic Sciences and Research, Sharda University, Greater Noida 201310, Uttar Pradesh, India; jatin.kumar1@sharda.ac.in (J.K.); amit.das@sharda.ac.in (A.K.D.); soumi.sadhu@sharda.ac.in (S.S.); swati.singh1@sharda.ac.in (S.S.); piyush.kumar1@sharda.ac.in (P.K.G.)

2 Department of Biotechnology, School of Engineering and Technology, Sharda University, Greater Noida 201310, Uttar Pradesh, India; sunita.sharma@sharda.ac.in

3 Department of Chemical Engineering, Chungbuk National University, Cheongju 28644, Korea

* Correspondence: pritam.kumar@sharda.ac.in (P.K.D.); bskim@chungbuk.ac.kr (B.S.K.)

check for updates

Citation: Dikshit, P.K.; Kumar, J.; Das, A.K.; Sadhu, S.; Sharma, S.; Singh, S.; Gupta, P.K.; Kim, B.S. Green Synthesis of Metallic Nanoparticles: Applications and Limitations. Catalysts 2021, 11, 902. https:// doi.org/10.3390/catal11080902

Academic Editor: Pierluigi Barbaro

Received: 20 June 2021

Accepted: 23 July 2021

Published: 26 July 2021

Publisher's Note: MDPI stays neutral with regard to jurisdictional claims in published maps and institutional affiliations.

Copyright: (c) 2021 by the authors. Licensee MDPI, Basel, Switzerland. This article is an open access article distributed under the terms and conditions of the Creative Commons Attribution (CC BY) license (https:// creativecommons.org/licenses/by/ $4.0 /)$.

\begin{abstract}
The past decade has witnessed a phenomenal rise in nanotechnology research due to its broad range of applications in diverse fields including food safety, transportation, sustainable energy, environmental science, catalysis, and medicine. The distinctive properties of nanomaterials (nano-sized particles in the range of 1 to $100 \mathrm{~nm}$ ) make them uniquely suitable for such wide range of functions. The nanoparticles when manufactured using green synthesis methods are especially desirable being devoid of harsh operating conditions (high temperature and pressure), hazardous chemicals, or addition of external stabilizing or capping agents. Numerous plants and microorganisms are being experimented upon for an eco-friendly, cost-effective, and biologically safe process optimization. This review provides a comprehensive overview on the green synthesis of metallic NPs using plants and microorganisms, factors affecting the synthesis, and characterization of synthesized NPs. The potential applications of metal NPs in various sectors have also been highlighted along with the major challenges involved with respect to toxicity and translational research.
\end{abstract}

Keywords: green synthesis; metal nanoparticles; wastewater treatment; agriculture; food application

\section{Introduction}

During the last two decades, nanotechnology has taken massive leaps to become one of the most researched and booming fields due to its applications in various fields of human welfare. Nanoparticles (NPs) are naturally occurring or engineered extremely small sized particles in the range of 1 to $100 \mathrm{~nm}$. They exhibit unique and valuable physical and chemical properties. At nanoscale, particles display better catalytic, magnetic, electrical, mechanical, optical, chemical, and biological properties. Due to high surface to volume ratio, NPs show higher reactivity, mobility, dissolution properties, and strength [1]. NPs are thought to have been present on earth since its origin in the form of soil, water, volcanic dust, and minerals. Besides their natural origin, humans have also started synthesizing NPs through various methods [2]. NPs and their derived nanomaterials are finding wide application in various sectors such as food, agriculture, cosmetics, medicines, etc. Application of NPs in food sector involves food processing and preservation (nanopreservatives, toxin detection, nanoencapsulated food additives, etc.) and food packaging (nanocoatings, nanosensors, nanocomposites, edible coating NPs, etc.) In agriculture, nanotechnology is being utilized for the production of nano-fertilizers, pesticides, herbicides, and sensors. In medicine, nanotechnology involves production of various antibacterial, antifungal, antiplasmodial, anti-inflammatory, anticancer, antiviral, antidiabetic, and antioxidant agents. Nanotechnology is also useful for the early detection of life-threatening diseases such as cancer. Besides, NPs have also been used for bioremediation due to their capacity to 
degrade various pollutants such as organic dyes and chemicals. Given the diverse scope of nanomaterials, different countries are investing in nanotechnology with USA and China emerging at the top. In 2019, the global market of different nano products was more than 8 billion US dollars, which is expected to show annual growth rate of around 13\% by 2027 .

Depending on their chemical composition, four major classes of NPs are described, such as carbon-based (nanotubes and nanofibers of carbon, etc.), metal and metal oxide based ( $\mathrm{Ag}, \mathrm{Cu}$, etc.), bio-organic based (liposomes, micelles, etc.), and composite based [3]. NPs can also be classified as organic and inorganic in nature [4]. Organic NPs are biodegradable in nature and include polymeric NPs, lipid based nanocarriers, liposomes, carbon-based nanomaterials, and solid lipid NPs, while inorganic NPs are based on inorganic materials comprising of metals and metal oxides such as silver oxide, zinc oxide, etc. Among all the synthesized NPs, silver NPs (Ag NPs) are the most widely employed, showing their dominance in various consumer products (more than 25\%) [5]. AgNPs are majorly used as antibacterial, antifungal, and antiviral agents. With each passing year, novel varieties of NPs are being developed using state-of-art technology having diverse applications in various sectors.

The synthesis of NPs can be carried out following two different approaches, viz., (i) top-down approach, and (ii) bottom-up approach [6,7]. Furthermore, three different strategies such as physical, chemical, and biological methods are adopted for the synthesis of NPs. A schematic representation of various methods adopted for NPs synthesis and its applications is depicted in Figure 1.

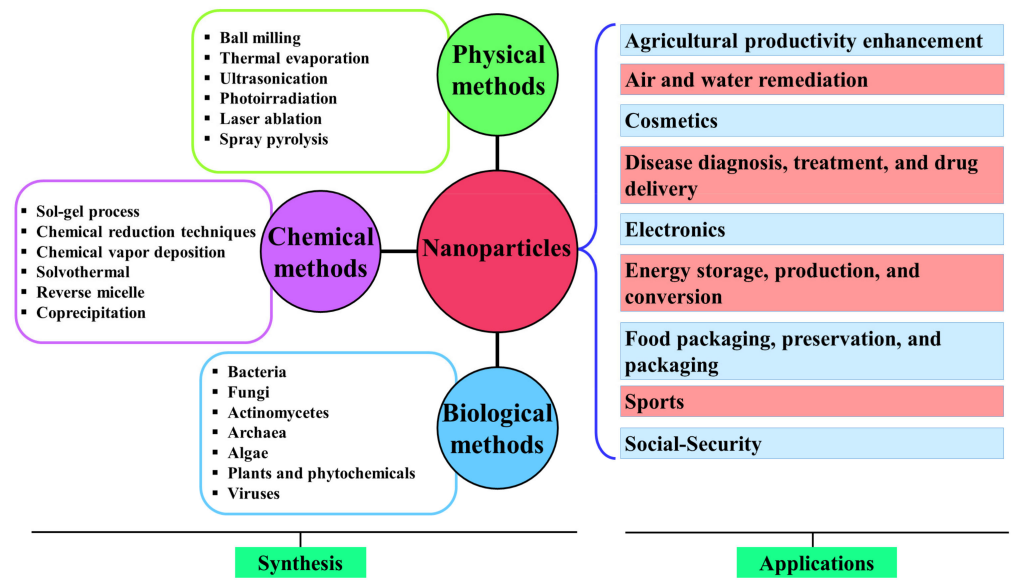

Figure 1. Schematic representation of various methods adopted for NP synthesis and its applications.

The physical methods belong to the category of top-down approach, while the chemical and biological methods follow the bottom-up approach for the synthesis NPs. Evaporation-condensation, electrolysis, diffusion, laser ablation, sputter deposition, pyrolysis, plasma arcing, and high energy ball milling are some of the most common physical methods used for the synthesis of NPs [8]. However, low production rate, expensive operations, and high energy consumption are the major limitations of these processes. Conversely, chemical synthesis methods that include chemical reduction, micro-emulsion/colloidal, electrochemical, and thermal decomposition are the conventional and most widely used methods for the synthesis of metallic NPs. The chemical reduction of NPs from their respective metal salt precursors by adding particular reducing agents is one of the most widely used methods for NPs chemical synthesis due to easy operational and equipment requirement. Several reducing agents, such as sodium borohydride $\left(\mathrm{NaBH}_{4}\right)$ [9], potassium bitartrate [10], formaldehyde [11], methoxypolyethylene glycol [12], hydrazine [13], etc., and stabilizing agents like dodecyl benzyl sulfate [14] and polyvinyl pyrrolidone [15] have been explored during synthesis. The chemical methods are economical for large-scale production; however, the use of toxic chemicals and production of harmful by-products cause environmental damage, thereby limiting its clinical and biomedical applications $[16,17]$. Hence, 
there is an increased demand for reliable, nontoxic, high-yielding, and eco-sustainable techniques for metallic NPs that can replace the conventional methods. The biological synthesis methods, therefore, provide an attractive alternative to the physicochemical synthesis methods.

The present article provides a critical overview on the synthesis of metallic NPs using biological methods and several factors affecting the preparation process. The applications of NPs in various sectors, such as medicine, wastewater treatment, agricultural sectors, etc., have been discussed in detail. Current challenges highlighting the toxic effects of NPs and future perspectives in each section gives us a comprehensive way forward in the near future.

\section{Biological Synthesis of NPs}

The biological synthesis of NPs can be carried out using a vast array of resources such as plants and plant products, algae, fungi, yeast, bacteria, and viruses. The synthesis of NPs is initiated by the mixing of noble metal salt precursors with biomaterials [18]. The presence of various compounds, such as proteins, alkaloids, flavonoids, reducing sugars, polyphenols, etc., in the biomaterials act as reducing and capping agents for the synthesis of NPs from its metal salt precursors [19]. The reduction of metal salt precursor to its successive NPs can be initially confirmed by visualizing the color change of the colloidal solution. Several studies reported the synthesis of $\mathrm{Ag}, \mathrm{Au}, \mathrm{Cu}, \mathrm{Pt}, \mathrm{Cd}, \mathrm{Pt}, \mathrm{Pd}, \mathrm{Ru}, \mathrm{Rh}$, etc. using various biological agents in the recent past.

\subsection{Plant-Mediated Synthesis of NPS}

Figure 2 shows the Scopus search (with keywords "metal nanoparticles" and "plant extract") results of the number of research published from last 10 years on biological synthesis of NPs. An increase in the number of research publications was observed with each year and approximately 468 publications reported in the year 2020. These data further corroborate that the research interest in the area of biological NPs using plant extract is increasing significantly every year.

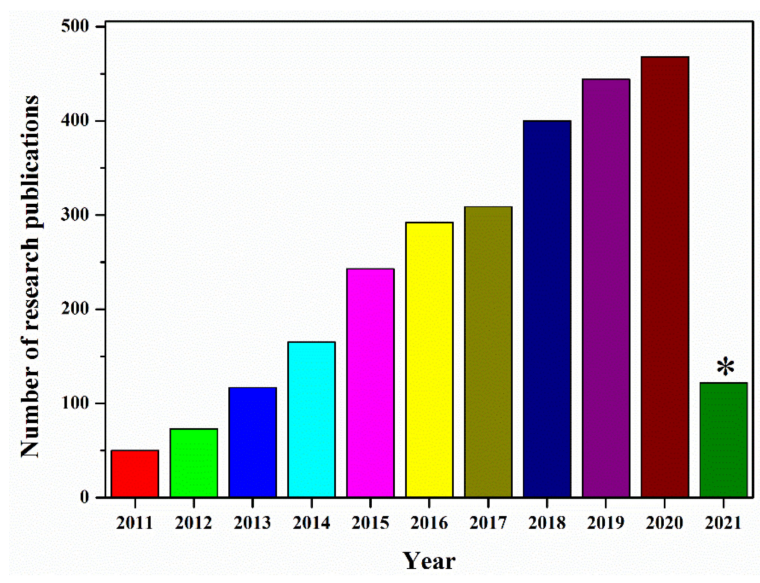

Figure 2. Number of research publications on biological synthesis of metallic NPs from last 10 years. Source: Scopus. ${ }^{*}$ Number of publications reported as on 10 May 2021.

Synthesis of a wide range of metallic NPs has been reported using various plants [6,20,21]. Plant mediated synthesis of NPs can be achieved by three different methods, viz., (i) intracellularly (inside the plant), (ii) extracellularly (using plant extracts), and (iii) using individual phytochemicals. Several plants have the capability of metal accumulation and successive conversion of these accumulated metals to NPs intracellularly. The presence of several biomolecules such as amino acids, alkaloids, aldehydes, flavones, ketones, proteins, phenolics, polysaccharides, saponins, tannins, terpenoids, and vitamins in the plant plays a key role in the reduction of metals [22]. The variation in the size, shape, and properties of 
accumulated NPs are observed due to the variation in stabilizing and reducing potential of biomolecules present in the plant. The formation of gold NPs inside the living plant, alfalfa was reported by Gardea-Torresdey et al. [23] when the plants were grown in $\mathrm{AuCl}_{4}$ rich environment. In a similar kind of study, Bali and Harris [24] observed the ability of Medicago sativa and Brassica juncea plants to accumulate Au NPs from aqueous solutions of $\mathrm{KAuCl}_{4}$. The NPs were majorly located in the xylem parenchyma cells while some were also accumulated throughout the epidermis, cortex, and vascular tissue.

However, for the past several years, most of the works have been focused on using the inactive part of the plants either in powder form or as an extract for the synthesis of NPs [25]. Table 1 summarizes the green synthesis of various metal NPs using plants. Various parts of plants such as leaves, steam, flower, fruit, root, latex, seed, and seed coat are being exploited for the synthesis of metallic NPs.

Table 1. Summary on synthesis of metallic nanoparticles by various plant species.

\begin{tabular}{|c|c|c|c|c|}
\hline Nanoparticles & Plant Species & Experimental Conditions & Shape and Size & References \\
\hline \multirow[t]{19}{*}{ Silver (Ag) } & Acalypha indica Linn & \multirow{6}{*}{$\begin{array}{c}\text { Temperature: } 27^{\circ} \mathrm{C} ; \mathrm{pH}: 7.0 \text {; duration: } 30 \mathrm{~min} \\
\text { Temperature: } 20-100^{\circ} \mathrm{C} \text {; } \mathrm{pH}: 2.0-10.0 ; \\
\text { duration: } 15 \mathrm{~min} \\
\text { pH: } 7.2-8.5 \\
\text { Temperature: } 30 \text { and } 60^{\circ} \mathrm{C} \text {; } \mathrm{pH}: 3.0-9.0 \\
\text { Temperature: } 60^{\circ} \mathrm{C} ; \mathrm{pH}: 8.0 \text {; duration: } 6 \mathrm{~h} \\
\text { Duration: } 60 \mathrm{~min}\end{array}$} & Spherical; $20-30 \mathrm{~nm}$ & [26] \\
\hline & Chenopodium album leaf & & Spherical; $10-30 \mathrm{~nm}$ & [27] \\
\hline & Hibiscus rosa sinensis leaf & & Spherical; $13 \mathrm{~nm}$ & [28] \\
\hline & Calendula officinalis seed & & Spherical; $7.5 \mathrm{~nm}$ & [29] \\
\hline & Allophylus cobbe leaf & & Spherical; 2-10 nm & [30] \\
\hline & \multirow{4}{*}{$\begin{array}{l}\text { Cissusquadrangularis leaf } \\
\text { Piper nigrum, Ziziphus Spina-Christi } \\
\text { and Eucalyptus globulus leaves } \\
\text { Phyllanthus emblica fruit } \\
\text { Blumea eriantha DC }\end{array}$} & & Spherical and cuboidal & [31] \\
\hline & & Temperature: ambient; duration: $1 \mathrm{~h}$ & Spherical; $8-35 \mathrm{~nm}$ & [32] \\
\hline & & \multirow{2}{*}{$\begin{array}{l}\text { Temperature: } 65^{\circ} \mathrm{C} \text {; duration: } 2 \mathrm{~h} \\
\text { Temperature: ambient; duration: } 2-3 \mathrm{~h}\end{array}$} & Spherical; $16.29 \mathrm{~nm}$ & [33] \\
\hline & & & Spherical; $50 \mathrm{~nm}$ & [34] \\
\hline & \multirow{7}{*}{$\begin{array}{c}\text { Brillantaisia patula, Crossopteryx febrif } \\
\text { and Senna siamea leaf } \\
\text { Ocimum tenuiflorum leaf } \\
\text { Annona squamosa leaf } \\
\text { Aloe leaf } \\
\text { Artocarpus heterophyllus Lam. } \\
\text { Seed } \\
\text { Trigonella foenum graecum seed } \\
\text { Andrographis paniculata }\end{array}$} & Temperature: $70^{\circ} \mathrm{C}$; duration: $24 \mathrm{~h}$ & Spherical; 45-110 nm & {$[35]$} \\
\hline & & \multirow{3}{*}{$\begin{array}{l}\text { Temperature: ambient; duration: } 10 \mathrm{~min} \\
\text { Temperature: ambient } \\
\text { Temperature: ambient; duration: } 20 \mathrm{~min}\end{array}$} & Spherical and ovoid; 7-15 nm & [36] \\
\hline & & & Spherical; $20-100 \mathrm{~nm}$ & [37] \\
\hline & & & Spherical; $20 \mathrm{~nm}$ & [38] \\
\hline & & Temperature: $121^{\circ} \mathrm{C}$; duration: $5 \mathrm{~min}$ & Irregular; 3-25 nm & [39] \\
\hline & & \multirow{3}{*}{$\begin{array}{c}\text { Duration: } 5 \mathrm{~min} \\
\text { Temperature: } 30-95^{\circ} \mathrm{C} \\
\text { Temperature: } 20-60^{\circ} \mathrm{C} ; \mathrm{pH}: 4.5-10.0 \text {; } \\
\text { duration: } 30-150 \mathrm{~min}\end{array}$} & Spherical; $17 \mathrm{~nm}$ & [40] \\
\hline & & & Spherical; $13-27 \mathrm{~nm}$ & [41] \\
\hline & Podophyllum hexandrum leaf & & Spherical; $12-40 \mathrm{~nm}$ & [42] \\
\hline & Syzygium cumini fruit & Temperature: ambient; $\mathrm{pH}$ : 7.0-9.0; duration: $2 \mathrm{~h}$ & Spherical; 5-20 nm & [43] \\
\hline & Crassocephalum rubens leaf & Temperature: $50^{\circ} \mathrm{C}$; duration: $20 \mathrm{~min}$ & Spherical and hexagonal; $15-25 \mathrm{~nm}$ & [44] \\
\hline \multirow[t]{15}{*}{ Gold $(\mathrm{Au})$} & Cassia fistula stem bark & Temperature: ambient & $\begin{array}{l}\text { Rectangular and triangular; } \\
55.2-98.4 \mathrm{~nm}\end{array}$ & {$[45]$} \\
\hline & Crassocephalum rubens leaf & Temperature: $50^{\circ} \mathrm{C}$; duration: $10 \mathrm{~min}$ & Spherical; $10-20 \mathrm{~nm}$ & [44] \\
\hline & Simarouba glauca leaf & Duration: $15 \mathrm{~min}$ & Spherical and prism; $<10 \mathrm{~nm}$ & [46] \\
\hline & Hygrophila spinosa & $\begin{array}{c}\text { Temperature: } 30-100^{\circ} \mathrm{C} \text {; } \mathrm{pH}: 2.0-12.0 \text {; duration: } \\
15-60 \mathrm{~min}\end{array}$ & $\begin{array}{l}\text { Spherical, polygonal, rod and } \\
\text { triangular; } 68 \mathrm{~nm}\end{array}$ & [47] \\
\hline & Croton Caudatus Geisel leaf & Temperature: ambient & Spherical; $20-50 \mathrm{~nm}$ & [48] \\
\hline & Moringa oleifera flower & Temperature: ambient; duration: $60 \mathrm{~min}$ & $\begin{array}{l}\text { Triangular, hexagonal, and spherical; } \\
5 \mathrm{~nm}\end{array}$ & [49] \\
\hline & Illicium verum & $\begin{array}{c}\text { Temperature: } 25-50{ }^{\circ} \mathrm{C} \text {; } \mathrm{pH}: 2.0-10.00 \text {; } \\
\text { duration: } 15 \mathrm{~min}\end{array}$ & Triangular and hexagonal; 20-50 nm & {$[50]$} \\
\hline & Terminalia arjuna leaf & Temperature: ambient; duration: $15 \mathrm{~min}$ & Spherical; $20-50 \mathrm{~nm}$ & [51] \\
\hline & Zingiber officinale & $\begin{array}{c}\text { Temperature: } 37 \text { and } 50^{\circ} \mathrm{C} \text {; } \mathrm{pH}: 7.4 ; \\
\text { duration: } 20 \mathrm{~min}\end{array}$ & Spherical; 5-10 nm & {$[52]$} \\
\hline & Rosa hybrida petal & Temperature: ambient; duration: $5 \mathrm{~min}$ & $\begin{array}{l}\text { Spherical, triangular, and hexagonal; } \\
\qquad 10 \mathrm{~nm} .\end{array}$ & [53] \\
\hline & Terminalia chebula seed & Temperature: ambient; duration: $20 \mathrm{~s}$ & $\begin{array}{l}\text { Triangular, pentagonal, and } \\
\text { spherical; 6-60 } 6 \mathrm{~nm}\end{array}$ & {$[54]$} \\
\hline & Eucommia ulmoides bark & $\begin{array}{c}\text { Temperature: } 30-60^{\circ} \mathrm{C} \text {; } \mathrm{pH}: 5.0-13.0 \text {; } \\
\text { duration: } 30 \mathrm{~min}\end{array}$ & Spherical & {$[55]$} \\
\hline & Acorus calamus rhizome & Temperature: ambient; $\mathrm{pH}$ : 4.0-9.2 & Spherical; $10 \mathrm{~nm}$ & [56] \\
\hline & Curcuma pseudomontana root & Temperature: ambient; duration: $30 \mathrm{~min}$ & Spherical shape; $20 \mathrm{~nm}$ & [57] \\
\hline & $\begin{array}{c}\text { Citrus limon, Citrus reticulata and Citrus } \\
\text { sinensis }\end{array}$ & Temperature: ambient; duration: $10 \mathrm{~min}$ & Spherical and triangular; $15-80 \mathrm{~nm}$ & {$[58]$} \\
\hline
\end{tabular}


Table 1. Cont.

\begin{tabular}{|c|c|c|c|c|}
\hline Nanoparticles & Plant Species & Experimental Conditions & Shape and Size & References \\
\hline \multirow{10}{*}{$\begin{array}{l}\text { Palladium } \\
\quad(\mathrm{Pd})\end{array}$} & $\begin{array}{c}\text { Hippophae rhamnoides } \\
\text { Linn leaf }\end{array}$ & Temperature: $80^{\circ} \mathrm{C}$; duration: $25 \mathrm{~min}$ & $2.5-14 \mathrm{~nm}$ & [59] \\
\hline & Cinnamom zeylanicum bark extract & Temperature: $30^{\circ} \mathrm{C}$; $\mathrm{pH}: 1.0-11.0$; duration: $72 \mathrm{~h}$ & Spherical; $15-20 \mathrm{~nm}$ & {$[60]$} \\
\hline & Banana peel extract & $\begin{array}{c}\text { Temperature: } 40-100^{\circ} \mathrm{C} ; \mathrm{pH}: 2.0-5.0 \\
\text { duration: } 3 \mathrm{~min}\end{array}$ & $50 \mathrm{~nm}$ & {$[61]$} \\
\hline & Cinnamomum camphora leaf & Temperature: ambient; duration: $12 \mathrm{~h}$ & $\begin{array}{l}\text { Quasi-spherical and irregular; } \\
3.6-9.9 \mathrm{~nm}\end{array}$ & {$[62]$} \\
\hline & Catharanthus roseus leaf & Temperature: $60^{\circ} \mathrm{C}$; duration: $2 \mathrm{~h}$ & Spherical; $38 \mathrm{~nm}$ & [63] \\
\hline & Terminalia chebula fruit & Temperature: ambient; duration: $40 \mathrm{~min}$ & - & {$[64]$} \\
\hline & Rosmarinus officinalis & Temperature: ambient; duration: $24 \mathrm{~h}$ & Semi-spherical; $15-90 \mathrm{~nm}$ & [65] \\
\hline & Anogeissus latifolia & Duration: $30 \mathrm{~min}$ & Spherical; $2.3-7.5 \mathrm{~nm}$ & {$[66]$} \\
\hline & Daucus carota leaves & - & $\begin{array}{l}\text { Rod; diameter-20 nm, } \\
\text { length-38-48 } \mathrm{nm}\end{array}$ & [67] \\
\hline & Camellia sinensis leaves & Temperature: $100{ }^{\circ} \mathrm{C}$; duration: $1 \mathrm{~h}$ & Spherical; $5-8 \mathrm{~nm}$ & [68] \\
\hline \multirow{5}{*}{$\begin{array}{l}\text { Platinum } \\
(\mathrm{Pt})\end{array}$} & Anacardium occidentale leaf & Temperature: ambient; $\mathrm{pH}: 6.0-8.0$ & Irregular rod shaped & [69] \\
\hline & Cacumen platycladi & Temperature: $30-90^{\circ} \mathrm{C}$; duration: $25 \mathrm{~h}$ & Spherical; 2-2.9 nm & {$[70]$} \\
\hline & Asparagus racemosus root & Duration: $5 \mathrm{~min}$ & $1.0-6.0 \mathrm{~nm}$ & [71] \\
\hline & Diopyros kaki leaf & Temperature: $25-95^{\circ} \mathrm{C}$ & Spherical and plate; $2-20 \mathrm{~nm}$ & [72] \\
\hline & Ocimum sanctum leaf & Temperature: $100{ }^{\circ} \mathrm{C}$; duration: $1 \mathrm{~h}$ & Rectangular and triangular; $23 \mathrm{~nm}$ & [73] \\
\hline \multirow[t]{4}{*}{$\begin{array}{l}\text { Copper } \\
(\mathrm{Cu})\end{array}$} & Mulberry fruit (Morus alba L.) & Temperature: ambient; duration: $5 \mathrm{~h}$ & $\begin{array}{l}\text { Spherical and non-regular; } \\
50-200 \mathrm{~nm}\end{array}$ & [74] \\
\hline & Crotalaria candicans leaf & - & Spherical; $30 \mathrm{~nm}$ & [75] \\
\hline & Ziziphus spinachristi fruit & Temperature: $80^{\circ} \mathrm{C}$ & Spherical; 5-20 nm & [76] \\
\hline & Clove (Syzygium aromaticum) buds & Temperature: $30^{\circ} \mathrm{C}$; duration: $15 \mathrm{~min}$ & Spherical; $15-20 \mathrm{~nm}$ & {$[77]$} \\
\hline \multirow[t]{3}{*}{ Iron $(\mathrm{Fe})$} & Tea leaves extract & Temperature: $80^{\circ} \mathrm{C}$; duration: $3 \mathrm{~h}$ & $30-100 \mathrm{~nm}$ & [78] \\
\hline & Moringa oleifera seeds & Temperature: ambient; duration: $30 \mathrm{~min}$ & Spherical; $2.6-6.2 \mathrm{~nm}$ & [79] \\
\hline & Trigonella foenum-graecum seed & Temperature: $30^{\circ} \mathrm{C}$; duration: $5 \mathrm{~min}$ & $7-14 \mathrm{~nm}$ & {$[80]$} \\
\hline \multirow[t]{3}{*}{$\begin{array}{l}\text { Selenium } \\
\text { (Se) }\end{array}$} & Ocimum tenuiflorum & Temperature: ambient; duration: $75 \mathrm{~h}$ & $\begin{array}{l}\text { Monodispersed and spherical; } \\
15-20 \mathrm{~nm}\end{array}$ & [81] \\
\hline & Murraya koenigii & - & Spherical; 50-150 nm & [82] \\
\hline & Zinziber officinale fruit & Temperature: ambient; $\mathrm{pH}$ : 9.0; duration: $75 \mathrm{~h}$ & Spherical; $100-150 \mathrm{~nm}$ & [83] \\
\hline \multirow[t]{2}{*}{ Nickel (Ni) } & Calotropis gigantea leaves & Temperature: $80^{\circ} \mathrm{C} ; \mathrm{pH}$ : 12.0 ; duration: $90 \mathrm{~min}$ & $60 \mathrm{~nm}$ & [84] \\
\hline & Desmodium gangeticum roots & Temperature: $80^{\circ} \mathrm{C}$; duration: $45 \mathrm{~min}$ & - & [85] \\
\hline
\end{tabular}

In general, the synthesis of NPs is carried out by mixing the plant biomass/extract with a metal salt solution at a desired temperature and $\mathrm{pH}$. The primary confirmation of NPs synthesis can be checked by looking at the color change of the solution. The experimental procedure for the synthesis of NPs using plant biomass is depicted in Figure 3.

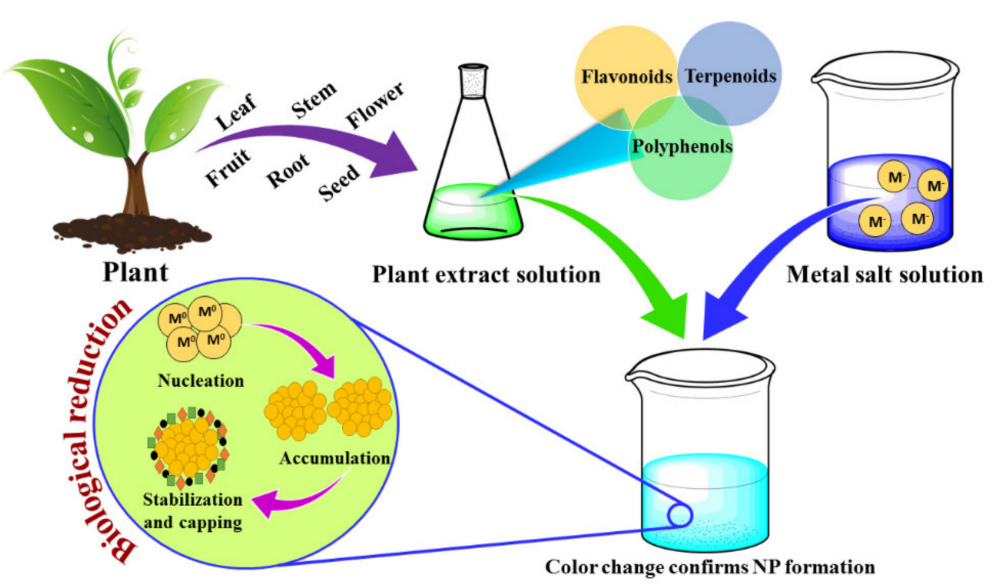

Figure 3. Schematic representation for plant-mediated biosynthesis of nanoparticles.

The plant extracts are prepared by using different methods such as hot extraction, cold extraction, and using Soxhlet apparatus, which were later used in NPs synthesis. This method of synthesis of NPs is more suitable in comparison to the intracellular method due to easy scale-up and downstream processing. Additionally, this method is renewable, non-toxic, biocompatible, and eco-friendly. Due to their biocompatible nature, these NPs are known to have various biological applications. The synthesis of metal NPs is 
initiated by adding the plant extract to the metal precursor solution containing the salts of respective metals. Metal precursor solutions such as $\mathrm{AgNO}_{3}, \mathrm{HAuCl}_{4}, \mathrm{PdCl}_{2}, \mathrm{H}_{2} \mathrm{PtCl}_{6}$, $\mathrm{Cu}\left(\mathrm{NO}_{3}\right)_{2} \cdot 3 \mathrm{H}_{2} \mathrm{O}, \mathrm{FeCl}_{3} \cdot 6 \mathrm{H}_{2} \mathrm{O}, \mathrm{Na}_{2} \mathrm{SeO}_{3}$, and $\left(\mathrm{NiNO}_{3}\right)_{2} \cdot 6 \mathrm{H}_{2} \mathrm{O}$ are commonly used for the synthesis of $\mathrm{Ag}, \mathrm{Au}, \mathrm{Pt}, \mathrm{Cu}, \mathrm{Fe}, \mathrm{Se}$, and Ni NPs. The synthesis of metal NPs using plant extract mainly occurs in three stages. In the first stage, the reduction of metal ions $\left(\mathrm{M}^{+}\right.$or $\mathrm{M}^{2+}$ ) to metal atoms $\left(\mathrm{M}^{0}\right)$ and successive nucleation of the reduced metal atoms occurs. While in the second stage, the coalescence of small adjacent NPs into larger size particles occurs with simultaneous increase in thermodynamic stability. At the final stage, the termination of the process takes place while giving the final shape to the NPs $[86,87]$. The presence of various active biomolecules in the plant extract plays an important role in the reduction and stabilization of metal ions in the solution. However, due to the presence of a large number of phytochemicals in the plant extract, it is difficult to ascertain the exact reducing and stabilizing agents for NPs synthesis.

Salih et al. [32] used plant extract derived from leaves of three different plants, viz., Piper nigrum, Ziziphus Spina-Christi and Eucalyptus globulus, for the synthesis of AgNPs. The average particle size distribution was in the range of 8-35 nm and decreased with the increase in concentration of plant extract. In a similar kind of study, Dhar et al. [33] reported the synthesis of AgNPs using fruit extract of Phyllanthus emblica. The fabricated AgNPs were spherical with an average size of $60-80 \mathrm{~nm}$. The extraction methods also play an important role which influences the antioxidant properties of Ag and Au NPs synthesized using leaves extract of Crassocephalum rubens [44]. Figure 4 depicts the size, shape, and morphological features of C. rubens synthesized AgNPs and AuNPs. The SEM and TEM images revealed spherical and hexagonal shapes of AgNPs with size 10-15 nm, whereas the size of AuNPs was in the range of 10-20 nm with spherical shape.
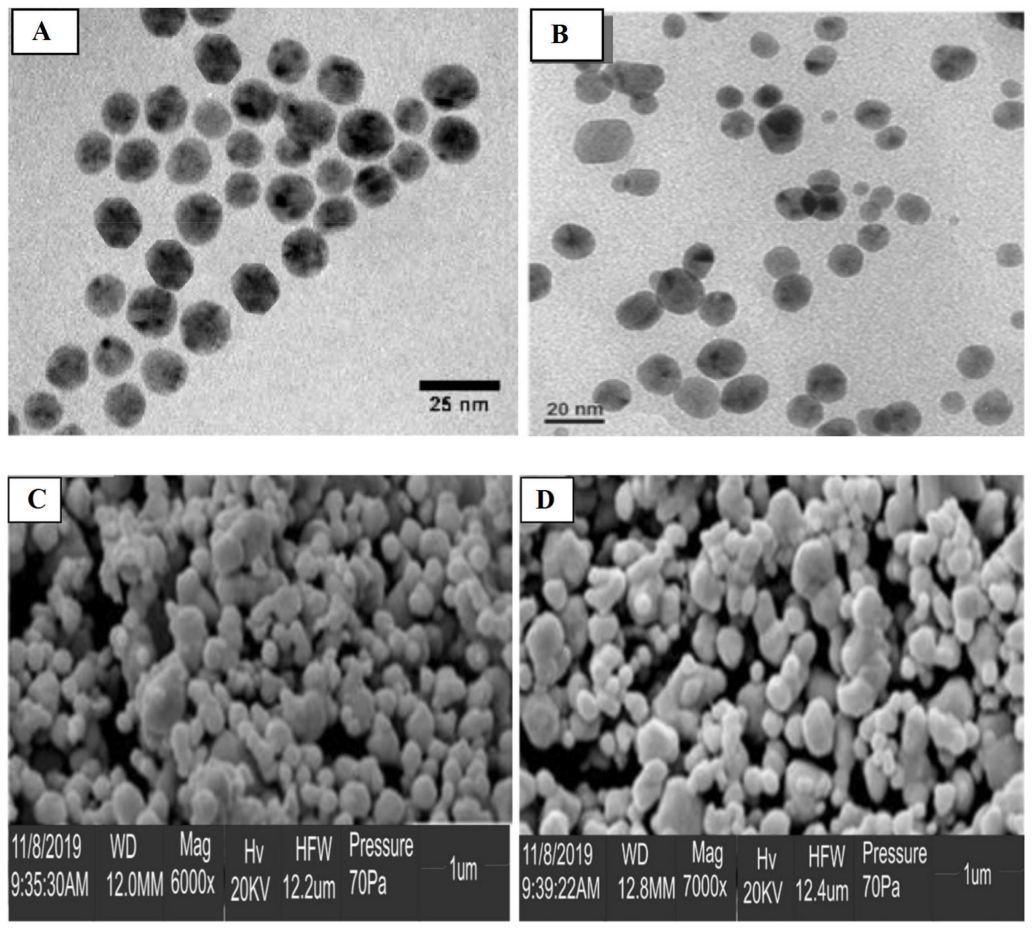

Figure 4. Characterization of AgNPs and AuNPs synthesized from Crassocephalum rubens leaf extract. TEM images of (A) AgNPs and (B) AuNPs; SEM images of (C) AgNPs and (D) AuNPs. Reprinted with permission from Reference [44].Copyright 2021 Elsevier.

The biosynthesized Au NPs using aqueous extract of Hygrophila spinosa exhibited enhanced cytotoxicity against various cancer cell lines compared to H. spinosa aqueous extract [47]. These green synthesized AuNPs with antioxidant and cytotoxic properties could provide a new direction for the development of nanomedicine. In addition to $\mathrm{Au}$ 
and Ag NPs, Pd NPs synthesized using Rosmarinus officinalis leaves extract demonstrated notable antimicrobial and antifungal activity against different bacteria and fungi [65]. Besides leaves, other plant parts such as root, fruit, flower, petal, seed, peel, bark etc. are used in the biosynthesis of different NPs $[40,49,53,55,61,71,80]$. Several previous studies tried to explain the mechanisms behind the antimicrobial effect of metallic NPs [88-90]. These metal ions could strongly interact with the negatively charged bacterial cell wall leading to its rupture. The other mechanism states distortion of the helical structure of bacterial DNA due to the interaction of NPs and interruption of internal and external cellular mechanisms.

\subsection{Microbial Synthesis of NPs}

In addition to the plant-mediated synthesis, several microorganisms such as bacteria, fungi, actinomycetes, and viruses are also reported to synthesize various metal NPs. The interaction between metals and microorganisms have been exploited in the past for various biological applications such as biomineralization, bioremediation, bioleaching, and biocorrosion [91]. However, recently microbial synthesis of NPs has emerged as a promising field of research due to certain advantages compared to other methods. The NPs are synthesized either intracellularly or extracellularly depending on the type of microorganisms [92]. Previous reports on the synthesis of metal NPs using various microorganisms have been summarized in Table 2.

Table 2. Summary on synthesis of metallic nanoparticles by microorganisms.

\begin{tabular}{|c|c|c|c|c|}
\hline & Microorganisms & Nanoparticles & Shape and Size & References \\
\hline \multicolumn{5}{|c|}{ Bacteria } \\
\hline & Bacillus subtilis & $\mathrm{Ag}$ & Spherical; 3-20 nm & [93] \\
\hline & Pseudomonas stutzeri & $\mathrm{Ag}$ & Triangular; $200 \mathrm{~nm}$ & [94] \\
\hline & Bacillus licheniformis & $\mathrm{Ag}$ & $40 \mathrm{~nm}$ & [95] \\
\hline & Ochrobactrum anhtropi & $\mathrm{Ag}$ & Spherical; $38-85 \mathrm{~nm}$ & [96] \\
\hline & Pantoea ananatis & $\mathrm{Ag}$ & Spherical; $8.06-91.31 \mathrm{~nm}$ & [97] \\
\hline & Actinobacter & $\mathrm{Ag}$ & Spherical; $13.2 \mathrm{~nm}$ & [98] \\
\hline & Pseudomonas aeruginosa & $\mathrm{Au}$ & $15-30 \mathrm{~nm}$ & [99] \\
\hline & Rhodopseudomonas capsulata & $\mathrm{Au}$ & Spherical; $10-20 \mathrm{~nm}$ & [100] \\
\hline & Escherichia coli DH5 $\alpha$ & $\mathrm{Au}$ & Spherical, triangles, and quasi-hexagons; $25 \mathrm{~nm}$ & [101] \\
\hline & Bacillus subtilis & $\mathrm{Au}$ & $\begin{array}{l}\text { Spherical, } 20-25 \mathrm{~nm} \\
\text {. }\end{array}$ & [102] \\
\hline & Mycobacterium sp. & $\mathrm{Au}$ & Spherical; $5-55 \mathrm{~nm}$ & [103] \\
\hline & Shewanella loihica & $\mathrm{Pt}$ & $1-10 \mathrm{~nm}$ & [104] \\
\hline & Shewanella oneidensis MR-1 & $\mathrm{Pt}$ & $2.83-61.03 \mathrm{~nm}$ & [105] \\
\hline & Jeotgalicoccus coquinae ZC15 & $\mathrm{Pt}$ & Spherical; $5.74 \mathrm{~nm}$ & [106] \\
\hline & $\begin{array}{l}\text { Shewanella loihica } \\
\text { S }\end{array}$ & $\mathrm{Pd}$ & $1-12 \mathrm{~nm}$ & [104] \\
\hline & Shewanella oneidensis MR-1 & $\mathrm{Pd}$ & $10-100 \mathrm{~nm}$ & [107] \\
\hline & Lysinibacillus sp. ZYM-1 & $\mathrm{Se}$ & Cubic; $100-200 \mathrm{~nm}$ & [108] \\
\hline & Bacillus subtilis & $\mathrm{Se}$ & Spherical; $50-400 \mathrm{~nm}$ & [109] \\
\hline & Lactobacillus acidophilus & $\mathrm{Se}$ & Spherical; 2-15 nm & [110] \\
\hline \multicolumn{5}{|c|}{ Fungi } \\
\hline & Rhizopus stolonifer & $\mathrm{Ag}$ & Spherical; $2.86 \mathrm{~nm}$ & [111] \\
\hline & Candida glabrata & $\mathrm{Ag}$ & Spherical; $2-15 \mathrm{~nm}$ & [112] \\
\hline & Trametes trogii & $\mathrm{Ag}$ & Spherical and rod; 5-65 nm & [113] \\
\hline & Trichoderma longibrachiatum & $\mathrm{Ag}$ & Spherical; $10 \mathrm{~nm}$ & [114] \\
\hline & Fusarium oxysporum & $\mathrm{Ag}$ & Spherical; $21.3-37 \mathrm{~nm}$ & [115] \\
\hline & Aspergillus terreus & $\mathrm{Ag}$ & Spherical; $7-23 \mathrm{~nm}$ & [116] \\
\hline & Ganoderma sessiliforme & $\mathrm{Ag}$ & Spherical; $45 \mathrm{~nm}$ & [117] \\
\hline & Candida albicans ATCC 10231 & $\mathrm{Ag}$ & Spherical; $10-20 \mathrm{~nm}$ & [118] \\
\hline & Cladosporium cladosporioides & $\mathrm{Au}$ & $60 \mathrm{~nm}$ & [119] \\
\hline & Trichoderma harzianum & $\mathrm{Au}$ & Spherical; $26-34 \mathrm{~nm}$ & [120] \\
\hline & Pleurotus ostreatus & $\mathrm{Au}$ & Spherical; $10-30 \mathrm{~nm}$ & [121] \\
\hline & Aspergillus sp. & $\mathrm{Au}$ & Spherical; $4-29 \mathrm{~nm}$ & [122] \\
\hline & Rhizopus oryzae & $\mathrm{Au}$ & Spherical and flower like structure; $16-43 \mathrm{~nm}$ & [123] \\
\hline & Penicillium chrysogenum & $\mathrm{Pt}$ & Spherical; 5-40 nm & [124] \\
\hline & Fusarium oxysporum f. sp. lycopersici & $\mathrm{Pt}$ & Triangle, hexagons, square, and rectangles; $10-50 \mathrm{~nm}$ & [125] \\
\hline & Fusarium oxysporum & $\mathrm{Si}$ & Quasi-spherical; 5-15 nm & [126] \\
\hline & Fusarium oxysporum & $\mathrm{Ti}$ & Spherical; 6-13 nm & [126] \\
\hline \multicolumn{5}{|c|}{ Yeast } \\
\hline & Rhodotorula sp. ATL72 & $\mathrm{Ag}$ & Spherical and oval; 8-21 nm & [127] \\
\hline & Saccharomyces cerevisiae & $\mathrm{Ag}$ & Spherical; $2-20 \mathrm{~nm}$ & [128] \\
\hline & Cryptococcus laurentii & $\mathrm{Ag}$ & $35-400 \mathrm{~nm}$ & [129] \\
\hline & Rhodotorula glutinis & $\mathrm{Ag}$ & $15-220 \mathrm{~nm}$ & [129] \\
\hline & Rhodotorula glutinis & $\mathrm{Ag}$ & Spherical; $15.5 \mathrm{~nm}$ & [130] \\
\hline & Saccharomyces cerevisiare & $\mathrm{Au}$ & Triangle, truncated triangle, and hexagon & [131] \\
\hline & Magnusiomyces ingens LHF1 & $\mathrm{Au}$ & Spherical and pseudo-spherical; $20-28 \mathrm{~nm}$ & [132] \\
\hline & Saccharomyces cerevisiae & $\mathrm{Pd}$ & Hexagonal; $32 \mathrm{~nm}$ & [133] \\
\hline & Magnusiomyces ingens LHF1 & $\mathrm{Se}$ & Spherical and quasi-spherical; $70-90 \mathrm{~nm}$ & [134] \\
\hline
\end{tabular}

Compared to other microorganisms, bacteria are preferred for the synthesis of NPs due to their easy maintenance, high yield, and low purification cost. In recent years, cell-free extract of endophytic bacterium, Pantoea ananatis, was used for the synthesis of AgNPs [97]. These synthesized spherical shaped NPs with an average size ranging from 8.06-91.32 nm exhibited significant antimicrobial activity against various pathogenic microorganisms. 
In a similar kind of study, Wypij et al. [98] reported maximum antimicrobial activity of AgNPs synthesized by using acidophilic actinobacterial strain against $E$. coli, followed by B. subtilis and S. aureus. Moreover, bacteria species belonging to Pseudomonas stutzeri, Bacillus licheniformis, Ochrobactrum anhtropi, Bacillus subtilis, and Actinobacter were used for the synthesis of AgNPs (Table 2). Gold NPs were synthesized by Pseudomonas aeruginosa, Rhodopseudomonas capsulate, Bacillus subtilis, Escherichia coli DH5 , Mycobacterium sp., etc. A larger amount of Actinobacter in the medium led to the formation of smaller size with uniformly distributed spherical AuNPs [135]. Intercellular and extracellular components of microorganisms play an important role in the synthesis of AuNPs [136]. Intercellular components such as reducing sugar, fatty acids, and enzymes and extracellular such as exopolysaccharides help in the reduction of AuNPs [136].

In addition to bacteria, the synthesis of NPs using fungi has received increasing attention due to various advantages such as easy scale-up and downstream processing, economic feasibility, and increased surface region due to the presence of mycelia. Different species of fungi such as Rhizopus stolonifera, Candida glabrata, Trametes trogii, Trichoderma longibrachiatum, Aspergillus terreus, Fusarium oxysporum, Ganoderma sessiliforme, Candida albicans ATCC 10231, Cladosporium cladosporioides, Trichoderma harzianum, Pleurotus ostreatus, Aspergillus sp., Rhizopus oryzae, etc. are used in silver and gold NPs synthesis. Other species of fungi such as Penicillium chrysogenum and Fusarium oxysporum are used for the synthesis of Pt, $\mathrm{Si}$, and Ti NPs.

Among the eukaryotic organism, yeast has been used for the synthesis of NPs like $\mathrm{Ag}$, Au, Pd, Se, etc. Soliman et al. [127] synthesized AgNPs using pink yeast Rhodotorula sp., and the characterization revealed the NPs to be spherical and oval in shape with 8.8-21.4 $\mathrm{nm}$ size. These biosynthesized AgNPs exhibited significant antimicrobial activity with complete inhibition to wide range of bacteria (i.e., both Gram positive and Gram negative) as well as fungi. Similarly, the antifungal activity of biosynthesized AgNPs using two yeasts: Rhodotorula glutinis and Cryptococcus laurentii was evaluated against the phytopathogenic fungi [129]. The results of this study revealed that the antifungal activity of AgNPs from R. glutinis was higher than that from the ones prepared from C. laurentii. In another study, the morphology and size of AuNPs were controlled by varying the $\mathrm{pH}$ of the medium containing yeast [131]. In this method, various morphologies of gold nanoplates such as triangle, truncated triangle, and hexagonal nanoplates with uniform size were synthesized successfully (Figure 5).

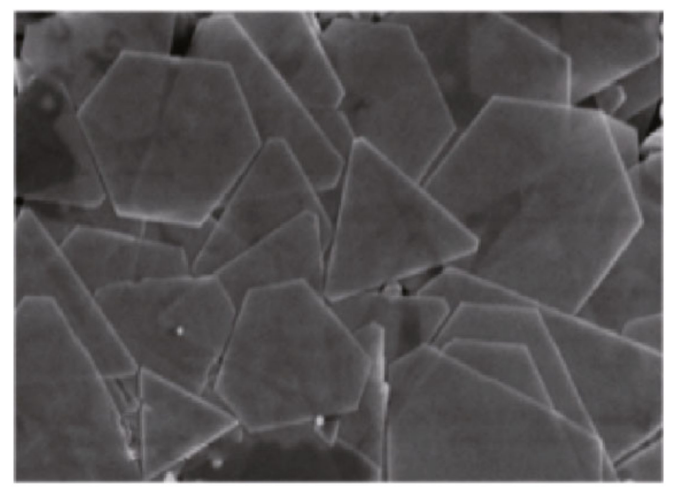

(A)

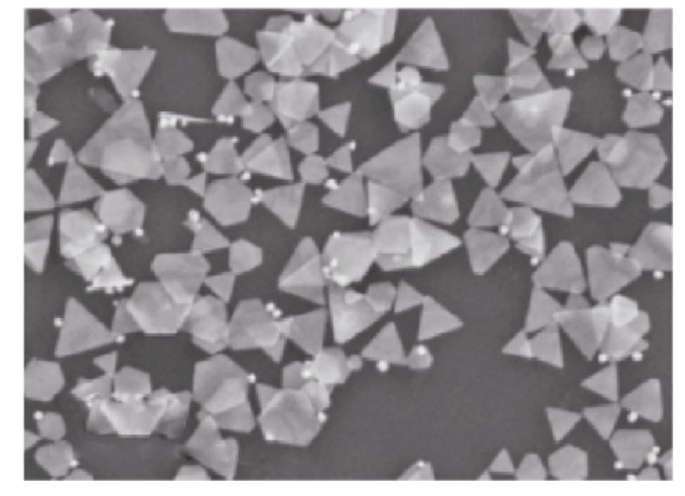

(B)

Figure 5. SEM images of gold nanoplates synthesized using yeast extract at different $\mathrm{pH}$ conditions. (A) Au nanoplates at low $\mathrm{pH}$ without $\mathrm{NaOH},(\mathbf{B})$ small Au nanoplates synthesized at high $\mathrm{pH}$. Reprinted with permission from Reference [131]. Copyright 2016 Springer Nature. 
Similarly, the palladium (Pd) and selenium (Se) NPs are synthesized using aqueous extract of Saccharomyces cerevisiae and cell-free extracts of Magnusiomyces ingens yeast, respectively [133,134].

The NPs are formed during the microbial synthesis process is due to the oxidation/reduction of metallic ions by secreted biomolecules by microbial cells such as enzymes, sugars, carbohydrates, proteins, etc. [137]. However, a complete understanding of microbial NP synthesis is still unknown as the routes for NPs synthesis varies for each kind of microorganisms. The reduction of silver for the synthesis of extracellular and intracellular AgNPs by bacteria is mainly achieved by the action of deoxyribonucleic acid (DNA) or sulfur-containing proteins, whereas in the case of fungi, the process is carried out by nitrate-dependent reductase or carboxylic group [138]. The extracellular synthesis method is preferable due to easy and simpler purification steps. In contrast, the intracellular NPs synthesis method is challenging and expensive due to the involvement of additional separation and purification processes. Fungal-mediated synthesis of NPs holds additional advantages compared to algae or bacteria in terms of easier and simpler biomass handling and downstream processes along with the secretion of large amount protein that further increases the productivity by several folds. However, the microorganism mediated NPs synthesis process is extremely intricate and difficult due to the preparation of inoculum and growth media, isolation of strain, and maintenance of culture medium and operation conditions ( $\mathrm{pH}$, temperature, agitation). Conversely, the use of plant extracts or broths is simple and convenient, devoid of the complex methods of cell culture and maintenance. The time required to achieve a complete reduction of NPs using microorganisms is usually 24 to $120 \mathrm{~h}$, while the reduction time is much less in using plant extract

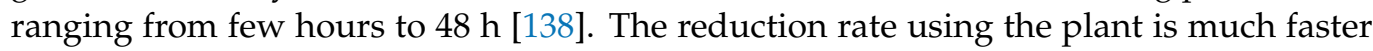
than microorganisms and in close agreement with the physical and chemical methods. The use of microorganisms for large-scale biosynthesis of NPs lacks feasibility compared with plants, which require less time for reaction completion. As reported in the earlier studies, the plant-mediated biosynthesis of AgNPs demonstrate better production rate, size, and morphological characteristics compared to other available biological techniques [138].

Hence, the plant-mediated synthesis of NPs proves to be a sustainable alternative not only to the other biological techniques but also to other synthesis methods such as physical and chemical. However, in-depth studies are required to understand the detailed mechanisms of action and to achieve better control over size, morphology, and production rate for making a plant-mediated synthesis method at par with chemical methods.

\subsection{Factors Affecting NPs Synthesis}

Adjustment of shape and size of metal NPs further enhances their functionality for various applications. The morphological parameters of NPs can be manipulated by changing various experimental parameters such as reaction time, reactant concentration, $\mathrm{pH}$, temperature, aeration, salt concentration, etc. [139]. Precise control of these parameters can play a critical role during the optimization of metal NPs synthesis via the biological route. The size and shape of NPs can be controlled by varying the $\mathrm{pH}$ of the medium, while the acid $\mathrm{pH}$ leads to the formation of large-sized NPs [140,141]. During synthesis of Au NPs using oat (Avena sativa) biomass, Armendariz et al. [142] observed smaller sized gold NPs at pH 3.0 and 4.0 in comparison to the synthesized NPs at pH 2.0. This is due to the better accessibility of functional groups present in the extract for nucleation at higher $\mathrm{pH}$ compared to the presence of fewer groups at a lower $\mathrm{pH}$ range. In addition to $\mathrm{pH}$, the concentration of biomolecules in the extract also affects the size and shape of synthesized NPs. Increase in the concentrations of Aloe vera leaf extract resulted in the synthesis of higher amount of spherical gold NPs instead of triangular which is due to the presence of carbonyl compounds in the extract [143]. In addition, the size of the NPs was modulated in the range of 50 to $350 \mathrm{~nm}$ by varying the extract concentration in the solution. The duration of reaction also plays a crucial role in the reduction of NPs and their size, which is primarily 
confirmed by rapid change in color of the reaction mixture. This duration can range from few minutes to few days.

A change in particle size of silver NPs was observed in the range of $10-35 \mathrm{~nm}$ by increasing the reaction time from $30 \mathrm{~min}$ to $4 \mathrm{~h}$ using Azadirachta indica leaf extract. Furthermore, the reaction temperature is one of the important parameters in the biological synthesis of NPs which also determines the shape, size, and yield of NPs. The average size of silver NPs decreased from 35 to $10 \mathrm{~nm}$ with the increase in reaction temperature from 25 to $60{ }^{\circ} \mathrm{C}$ using Citrus sinensis (sweet orange) peel extract [144].

\subsection{Characterization of NPs}

NPs have attracted significant attention of researchers due to their unique physical, chemical, and mechanical properties. Therefore, the physicochemical characterization of synthesized NPs is critically important before its application in various sectors. Analyzing various characteristics such as size, shape, surface morphology, surface area, structure, stability, elemental and mineral decomposition, homogeneity, intensity, etc. will provide important information about the NPs, which subsequently determined their end-use applications. Additionally, the electrical and thermal conductivity and purity of NPs can also be obtained by using these techniques. Size and shape of the synthesized NPs are mainly analyzed using X-Ray Diffraction (XRD), Scanning Electron Microscope (SEM), Field Emission Scattering Electron Microscopy (FESEM), Transmission Electron Microscopy (TEM), High-Resolution Transmission Electron Microscopy (HRTEM), Atomic Force Microscopy (AFM), Dynamic Light Scattering (DLS), Condensation Particle Counter (CPC), Photon Correlation Spectroscopy (PCS), etc. Among these techniques, XRD, SEM, and TEM are most commonly used for this purpose. Further, SEM, TEM, AFM, etc. are used for studying the surface morphology. Superconducting Quantum Interference Device (SQUID), Vibrating Sample Magnetometer (VSM), Electron paramagnetic resonance (EPR), etc. are used for the determination of magnetic properties of NPs. More details about NPs characterization techniques are reviewed by previous authors $[145,146]$.

\section{Potential Applications of Metal NPs}

These synthesized metallic NPs offer a diverse platform for various applications. Some of the most important applications of these metallic NPs are summarized in this section.

\subsection{Agriculture}

Nanotechnology has proven its potential to benefit the agriculture sector by finding solutions to agricultural and environmental problems in order to increase food production and security [147].

\subsubsection{Effect of Nano Material on Plants}

Seed germination and later growth phases benefit from nano-growth stimulants [148,149]. Owing to the small size and large surface area of nanoparticles, these particles are able to seep into the seed pores eventually activating the phytohormones required for seed growth and germination [150,151]. For example, the use nano- $\mathrm{TiO}_{2}$ and nano- $\mathrm{SiO}_{2}$ on soybean seedlings improved nitrate reductase activity thereby enhancing seed germination. However, combining both nanomaterials (NMs) was more advantageous [152]. Seed treatment with 0.25 percent $\mathrm{TiO}_{2}$ improved nitrogen assimilation and photosynthesis rate in spinach (Spinacia oleracea L.), resulting in better growth $[153,154]$. Watermelon (Citrullus lanatus) seed soaking in $\mathrm{Fe}_{2} \mathrm{O}_{3}$ NPs improved germination and initiated plant development and fruiting behavior [155]. The use of low-concentration $\mathrm{SiO}_{2} \mathrm{NPs}$ on tomato seeds improved germination [156]. Nanomaterials can be used in a variety of ways in in-vitro cultivation. $\mathrm{Zn}$ as a $\mathrm{ZnO}$ nanomaterial resulted in an increased calli growth and physiological parameters in tobacco (Nicotiana tabacum L.). Although nanoparticles have been widely utilized for promoting plant growth $[149,157]$, NM application may also be phytotoxic [158]. The positive and negative effects, however, are dependent on the 
dose, size, time, exposure, and make (synthetic/biological) of the NM [158,159]. Over the past years, application of chemically or physically synthesized NM have proven to be stimulant of plant growth; however, they pose a greater threat to ecology and environment (by seeping through the soil) [160]. Utility of green/biological NM in agriculture has therefore been advantageous due to their safety and feasibility [161]. An increased usage of biologically synthesized $\mathrm{Au}, \mathrm{Ag}, \mathrm{Ti}, \mathrm{Ca}, \mathrm{N}, \mathrm{Fe}$ nanoparticles either in form of nanofertilizers or nanopesticides has been employed [161-165].

\subsubsection{Application of Nanomaterials in the Field of Agriculture}

Over the recent years, application of nanomaterials to boost agriculture has broadly been in two major forms, either as nanofertilizers, to enhance the agricultural productivity or in the form of nanopesticides, to eradicate the pest/pathogens/weeds hampering the growth of crop plants. In this section, we will be discussing the applicability of nanofertilizers and nanopesticides, in current agricultural practices.

\section{Nanofertilizers}

Huge increase in agricultural yields, particularly grain yields, has played an important role in providing the world's food demands over the last five decades. In this context, increased usage of chemical fertilizers acts as one of the key contributors to increased crop productivity. Although, use of chemical fertilizers has increased productivity of crops, their poor use efficiency due to volatilization and leaching has led to its excessive usage [147]. On the contrary, nanofertilizers are compounds that are applied in smaller amounts and can enhance the effect of fertilizers [166]. Enhancing the effect of fertilizers on plants is usually done by governing the fertilizers in nano form which results in controlled nutrient release, eventually minimizing the risk of environmental damage [167]. With the recent advancement in the field of nanobiotechnology, nanofertilizers can be utilized as intelligent fertilizers which are able to release desired amount of nutrients just when and where they are needed by plants, thereby limiting the conversion of excess fertilizers to gaseous forms or leaking downstream [168].

To date, various NPs have been employed in developing fertilizers, some of which include hydroxyapatite, polyacrylic acid, clay minerals, chitosan, zeolite, and many more. The small size and large surface area of these NPs give them an advantage over the conventional fertilizers. For example, strong interactions of hydroxyapatite with urea lead to release of nitrogen from urea until 60 days as compared to the ammonium nitrate fertilizer (normal form of urea) which releases nitrogen only until 30 days [169].

Nanofertilizers can be broadly classified into three categories: (1) nanoparticulate nano fertilizers, (2) micronutrient nanofertilizers, and (3) macronutrient nanofertilizers. Nanoparticulate nanofertilizers include NPs, such as $\mathrm{CNTs}, \mathrm{TiO}_{2}$, and $\mathrm{SiO}_{2}$, responsible for plant growth. In soybean, an amalgamation of $\mathrm{TiO}_{2}$ and $\mathrm{SiO}_{2}$ results in overall increase in plant growth with increased nitrogen fixation and improved seed germination [152]. As utility of $\mathrm{TiO}_{2}$ nanoparticle in plant growth has been well established, recently several works have been done for generation of non-toxic, cheap, and environmentally safe green synthesized $\mathrm{TiO}_{2}$ from plant extracts of Syzgium cumini, Moringa oleifera, Cucurbita pepo, and Trigonella foenum [170-173]. Micronutrients such as molybdenum (Mo), copper (Cu), iron $(\mathrm{Fe})$, nickel $(\mathrm{Ni})$, manganese $(\mathrm{Mn})$, and Zinc $(\mathrm{Zn})$ packed in NPs serve as micronutrient nano fertilizers. A mixture of three micronutrients NPs $(\mathrm{ZnO}, \mathrm{CuO}$, and $\mathrm{B} 2 \mathrm{O} 3)$ has been successfully established to ameliorate drought stress in soybean plants [174]. Recent studies on Zea mays have revealed utility of biologically synthesized micronutrient nanofertilizers (iron oxide nanorods) in better plant growth as compared to the chemically synthesized NPs [164]. Similar to micronutrients, macronutrient nanofertilizers are composed of a combination of macroelements ( $\mathrm{Mg}, \mathrm{K}, \mathrm{N}, \mathrm{Ca}$, and P) [167]. Foliar application of $\mathrm{Mg}$ and Fe NPs on Vigna unguiculata, resulted in increased seed weight and photosynthesis ability thereby resulting in an overall improvement in yield [175]. When compared to crops administered with conventional fertilizer, phosphatic nanofertilizers have been attributed 
a 32 percent rise in growth rate and a 20 percent rise in seed production in soybean (Glycine max L.) [176]. A recent study on application of green synthesized multinutrient nanofertilizer (U-NPK) made from calcium phosphate NP doped with potassium and nitrogen resulted in reduction of $40 \%$ of nitrogen requirement of plants when compared to conventional approach due to slow and gradual release of major micronutrients [165]. Overall, use of nanofertilizer results in reduction in usage of fertilizer amount by allowing slow-release products.

\section{Nanopesticide}

Plants being sessile in nature are prone to various biotic and abiotic stresses such as pests, pathogens, heat, drought, pollution, etc. These stresses directly or indirectly affect the total yield of a plant. The ill effect of pathogens on an entire crop leading to famine like situations has been extensively studied by far, and in order to have a control over these forms of biotic stress, use of pesticides had been advocated. Utility of pesticides has been established in eradication of harmful pests and pathogens from crop field resulting in crop protection [177]. However, it has been found that use of pesticides leads to deleterious effects on environment and human health. As a result, numerous pesticides have been prohibited by state or international governments. Thus, development of effective yet safe pesticides is the need of the hour. Although biopesticides have emerged as a breakthrough, their use has been limited due to significantly higher cost of production. However, nanotechnology offers a new and better approach by introduction of nanopesticides [178].

One of the widely used examples of nanopesticide is nanostructured alumina (NSA). NSA acts as negatively charged insecticide which interacts with the positively charged bodies of the insects leading to dehydration. The dehydration of insect body results in detachment of insect's cuticle eventually leading to death [167]. Potent insecticidal activity of several other NPs has also been studied over past few years. In the year 2013, Paret et al. [179] studied the antimicrobial effect of $\mathrm{TiO}_{2}$ and $\mathrm{ZnO}$ NPs against X. perforans, casual organism of tomato spot disease. Role of Imidacloprid (IMI) as an effective systemic insecticide against several sucking insects such as Martianus dermestoides has been established; in addition, use of the nano-IMI being more photodegradable increases its effectiveness and environmental safety over the conventional formulation [180]. Another study found that nanoformulation of permethrin had a higher absorption than the conventional form against Aedes aegypti. In a recent study, Zhao et al. investigated the insecticidal activity of Cu NPs which showed potential upregulation of exogenous microbial protein within plant tissue enhancing resistance against the bollworm, under the effect of at a low dose of Cu NPs [181]. These findings are encouraging for utility of nanopesticides against various crop pests which could be an important tool in future agricultural pest management practices [147].

\subsection{Nanoparticles in Food Industry}

NPs in combination with other technologies can bring impactful innovations in the production, storage, packaging and transportation of food products. Food processing transforms raw food ingredients into a palatable format with long shelf-life and in turn, ensure efficient marketing and distribution systems for the enterprise. Fresh foods, on the other hand, require robust logistics for their transportation from source to consumer. Nanotechnology based systems play an important role to maintain the functional properties by incorporating NP based colloids, emulsions, and biopolymers solutions. Nanotechnology has provided with a new dimension and ample opportunities to develop NPs for various applications with deeper knowledge of the material. Application of nanotechnology in food industry is based on nanostructures which target food ingredients as well as sensors. Nano-food ingredients cover a wide area of applications starting from processing of food to its packaging. Nanostructure based application in food processing comprises the use as antimicrobial agents, nanoadditives, nanocarriers, anticaking agents, and nanocomposites while in food packaging, they are applied as nano-sensors for monitoring the quality of 
food produced [182]. The nano materials can also serve as enzyme-supports because of their large surface-to-volume ratio with respect to their conventional macro-sized counterparts. Recent nano-carriers have the potential to function as selective and exclusive delivery systems in order to carry the food additives into the food ingredients without altering the basic physicochemical properties and morphologies. For delivery of the bioactives to the target sites, particle size is the most essential factor that affects the delivery rate as the micro particles cannot be assimilated in some cell lines. A number of researchers have developed various techniques of encapsulating these bioactives using nano-sized particles or nano-emulsions resulting in enhancement of their bioavailability due to the increased surface to volume ratio. Nanoencapsulation using nano-spray-drying is another promising technique for the development of nanoparticles which can serve the food industry for the production of bioactive ingredients.

However, challenges related to performance and toxicity of nanomaterials need to be addressed to induce active development and applications of NPs. Additionally, legislation for regulating the production, application, and disposal of nanomaterials for food industry is of utmost importance. Public awareness and acceptance of the novel nano-enabled food and agriculture products are also needed to be strengthened.

\subsubsection{Application of NPs in Food Preservation and Packaging}

The utility and global market of NPs have developed manifold in the recent years and is expected to reach USD 125.7 billion by 2024. In the domain of food packaging, the market is expected to reach a staggering USD 44.8 billion by 2030 [183]. Nanoceuticals and Nutrition-by-nanotech are the available commercial names for food nano-supplements. Nano-sized powders and nanocochleates are used for increasing absorption and delivery of nutrients without altering the taste, flavor, and color of the food products. For better absorption of micronutrients, vitamin spray-induced nanodroplets are used. The technique of nano-encapsulation is involved when probiotics and similar targets are required to deliver into the human system with the help of Fe and $\mathrm{Zn}$ nanostructured capsules. NP based food supplements are more effective than their common counterparts because they are able to react more efficiently with the human cells due to their nano-size.

Food preservation systems with antimicrobial packaging provide advanced barrier properties to the food [184]. NPs or nanocomposite materials such as starch and sorbic acidbased films are being utilized in various packaging applications for their microbial growth inhibiting properties. They are effective due to their high surface-to-volume ratio as well as enhanced surface reactivity of the nano-sized antimicrobial agents which assists in inactivating microorganisms more efficaciously in comparison to micro- or macroscale agents. Metallic and semiconducting NPs are the commonly used antimicrobial NPs. Metallic NPs such as $\mathrm{Ag}$ with $\mathrm{Cu}, \mathrm{Au}$, and $\mathrm{Pt}$ demonstrate different degree of efficacies. Among the semiconducting $\mathrm{NPs}, \mathrm{TiO}_{2}, \mathrm{ZnO}, \mathrm{WO}_{3}$, and $\mathrm{MgO}$ are proven antimicrobial agents. Other antimicrobial NPs consist of natural biopolymers like chitosan (CTS) and enzymes (peroxidase, lysozyme), organically modified nanoclay (e.g., quaternary ammonium-modified MMT, Ag-zeolite), natural antimicrobial agents (e.g., nisin, thymol, carvacrol, isothiocyanate, and antibiotics) along with synthetic antimicrobial agents (quaternary ammonium salts, ethylenediaminetetraacetic acid (EDTA), propionic, benzoic, and sorbic acids) [185]. Hybrid metal-polymer matrices is a new class of materials for diverse applications due to their distinct properties such as high surface areas, orderly crystalline structures, and pores with regular size and shape. Sensor composed of graphene oxide-nickel nanoparticle biopolymer films is capable of measuring glucose concentration in the body fluids. Nevertheless, it can also be employed in food application system because of the use of biocompatible materials low toxicity of Ni and cost-effective technology [186,187]. The antibiotic resistance mechanisms are irrelevant to the development of NPs since their mode of action is only to stay in direct contact of the microbial cell walls without penetrating it. The barriers that the natural NPs create can control microbial growth and consequently spoilage of pathogens. Ag-NPs are used in biotexiles, electrical appliances, refrigerators, 
and other kitchen-wares as they act in bulk form and their ions have the ability to inhibit a wide range of biological processes in bacteria [188]. The incorporation of AgNPs into the gelatin-based nanocomposite film promisingly enhanced its antimicrobial activity. Further, it was observed that nanocomposites, thus developed, showed potential antibacterial properties against both Gram-negative and Gram-positive food-borne pathogens [189]. $\mathrm{ZnO}$ NPs have antibacterial nature which increases with decreasing particle size that can further be stimulated using visible range light to incorporate in various polymers including polypropylene [190]. The contamination of Escherichia coli can be inhibited by using $\mathrm{TiO}_{2}$ as a coating in packaging material, and in combination with $\mathrm{Ag}$, it improves various disinfection processes.

Recent development of smart packaging, viz., oxygen scavengers, moisture absorbers, and barrier-packaging products, account for $80 \%$ of the market share. Bakery and meat industries significantly use nano-enabled packaging technologies. The food environment is so enabled that it can continuously sense oxygen content, temperature, and microbial load. Some examples include Ag-NP-incorporated enzymes for microbial detection and gas sensing and nanofibrils of perylene-based fluorophores for detecting gaseous amines from fish and meat spoilage. Additionally, $\mathrm{ZnO}$ and $\mathrm{TiO}_{2}$ nanocomposites are used for detection of volatile organic compounds. Applications of NPs in the food industry are relatively recent and have demonstrated rapid developments in this area [191]. The major developments in this area include texture alteration, components and additives encapsulation, enhancing sensory acceptance, controlled release of flavor, and enhancing bioavailability of micronutrients [192]. NPs have also altered the novelty of packaging materials enhancing their mechanical barrier and antimicrobial efficacy. Hence, the recent advancements using NPs in food preservation and packaging may be used to overcome the disadvantages of the biopolymer-based packaging technologies. Nanocomposites exhibit enhanced barrier and mechanical and thermal properties compared to their polymers and conventional counterparts.

\subsubsection{Applications of NPs in Food Supplements and Value Addition}

The applications of nanotechnology and the use of NPs in food science and technology appear to have emerged from various sectors viz., pharmaceuticals, cosmetics, and nutraceuticals. The advent of nanomaterials, which can interact with biological entities at a near-molecular level makes it a common technology almost for various industries including the above. Current nanotechnology applications in food industry for developing nanotextured food constituents as well as the delivery systems for nutrients require techniques of nanoemulsions, surfactant micelles, emulsion bilayers, and reverse micelles. The nanotextured food ingredients claim to offer better texture, taste, and overall acceptability [193]. Low fat nanotextured spreads, mayonnaise, ice creams, and similar products claim to be as "creamy" as their full-fat alternatives, while offering a healthier alternative to the consumers.

Nanocochleates (50 nm in size), known to protect micronutrients and antioxidants from degradation during processing and storage, are based on a phosphatidylserine carrier derived from soybean and are generally regarded as safe. The Greek term "cochleate" means a 'snail with a spiral shell'. It can be derived by adding calcium ions to small phosphatidylserine vesicles in order to influence the formation of discs which are then fused to large sheets of lipid molecules and finally rolled up into nanocrystals.

In another instance, self-assembled nanotubes were developed from a protein namely lactalbumin which is a natural alternative for nanoencapsulation of pharmaceuticals, nutrients, and supplements [194]. Nanotechnology comprises another major area, namely nanoencapsulation, which is effectively used for delivering susceptible food ingredients and additives. Microencapsulation can be employed to mask the taste and odor of tuna fish oil for enabling it to be used for supplementation for its rich omega-3 fatty acid content. Nanoencapsulated food ingredients and additives are used in a range of food products such as the delivery of live probiotic microbes for healthy metabolic function. Nanoemulsion is 
another use in food technology to improve the quality of sweeteners, processed foods, and beverages [195-197]. A summary on application of NPs in various aspects of food science and technology is given in Table 3.

Table 3. Applications of NPs/Nanotechnologies in various aspects of Food Science and Technology.

\begin{tabular}{|c|c|c|c|}
\hline Application & NPs/Nanotechnology & Function & Reference \\
\hline \multirow{4}{*}{ Food Production } & $\mathrm{TiO}_{2}$ & $\begin{array}{l}\text { Antimicrobial, coating in packaging material, } \\
\text { detection of volatile compounds }\end{array}$ & [198] \\
\hline & Nanoemulsion & $\begin{array}{l}\text { Quality enhancement of beverages, } \\
\text { sweeteners, and processed food }\end{array}$ & [195-197] \\
\hline & Nanoencapsulation & $\begin{array}{l}\text { Enhancement of taste, color, and odor of food } \\
\text { materials }\end{array}$ & [194] \\
\hline & AgNPs, Ag-ZnO NPs & $\begin{array}{l}\text { Packaging of meat, fruit, and dairy products } \\
\text { by AgNPs-doped nondegradable and edible } \\
\text { polymers and oils; antimicrobial property }\end{array}$ & [199] \\
\hline \multirow{6}{*}{$\begin{array}{l}\text { Food preservation and } \\
\text { packaging }\end{array}$} & $\begin{array}{l}\text { Low-density polyethylene film }+\mathrm{Ag}, \mathrm{ZnO} \\
\mathrm{NPs}, \mathrm{TiO}_{2}, \text { kaolin }\end{array}$ & Orange juice, blueberry, strawberry & [200-202] \\
\hline & Ethylene vinyl alcohol + AgNPs & $\begin{array}{c}\text { Chicken, pork, cheese, lettuce, apples, peels, } \\
\text { eggshells }\end{array}$ & [203] \\
\hline & Polyvinylchloride + AgNPs & Minced beef & [204] \\
\hline & Polyethylene $+\mathrm{Ag}, \mathrm{TiO}_{2} \mathrm{NPs}$ & $\begin{array}{c}\text { Fresh apples, white sliced bread, fresh carrots, } \\
\text { soft cheese, atmosphere packaging milk } \\
\text { powder, fresh orange juice }\end{array}$ & {$[205,206]$} \\
\hline & Nanoclay-polymer nanocomposites & $\begin{array}{l}\text { Meats, cheese, confectionery, cereals, } \\
\text { boil-in-the-bag foods, extrusion-coating } \\
\text { applications for fruit juices and dairy products, } \\
\text { bottles for beer and carbonated drinks }\end{array}$ & [207] \\
\hline & Ag-ZnO NPs & $\begin{array}{l}\text { Nanostorage containers, bakeware, containers, } \\
\text { cutting boards }\end{array}$ & [199] \\
\hline \multirow{5}{*}{$\begin{array}{l}\text { Food supplement and value } \\
\text { addition }\end{array}$} & ZnNPs & Preservation and transport & [208] \\
\hline & Colloidal metal nanoparticles & Enhanced uptake & - \\
\hline & Nanopowders & Increase absorption of nutrients & - \\
\hline & Cellulose nanocrystal composites & Drug carrier & - \\
\hline & Nanocochleates & $\begin{array}{l}\text { Drug delivery, enhancement of taste and color } \\
\text { of food materials }\end{array}$ & - \\
\hline
\end{tabular}

Various applications of NPs and nanotechnology provide numerous advantages for food quality and safety. From farm to fork, nanotechnology is proven impactful at every stage of food manufacturing, enhancing shelf-life, nutrition, quality control, and smart packaging. However, the unregulated applications of NPs can pose potential risks to human health and environment. Numerous studies have demonstrated the toxicological effects of NPs on biological systems. Since food contact materials are already available in the market in some countries, more data on the safety of such engineered NPs on human health are necessary to implement regulations for such products. More research on ecotoxicological effects of NPs will add on to the existing knowledge.

\subsection{Drug and Medicine}

Nanotechnology-based drugs have attracted a lot of attention in the last decade. The unique properties of NPs, viz., small size, ability to travel through fine blood capillaries, vessels, junctions, and barriers, have made them one of the most researched and studied domains [209]. They have great advantages in terms of improvement of bioavailability of drugs, solubility, toxicity safeguard, pharmacological activities, distribution, and prevention from chemical and physical degradation and increased stability of drugs inside the body [210]. Nanomedicines have shown higher capacity to bind with biomolecules as well as reduction of inflammation/oxidative stress in tissues. Thousands of different nanomedicines have been designed over the years; they have various applications in different types of diseases. Few are approved for clinical use, and many more are in the phase of clinical trials.

The use of nanomaterials as drugs and medicine implies nanotechnologies for medical application with highly advanced medical intervention at molecular levels to cure diseases. 
It provides a platform for the discovery of therapeutic nanomaterials or nanomedicines. The growth in nanomedicines has introduced numerous possibilities in medical sciences, specifically in the drug delivery mechanisms. Their structural characteristics make them an excellent mode for targeting at specific sites and quick penetration inside the cell/diseased sites [211]. Depending on their application and origin, various types of NPs were discovered based on therapeutic need. Liposomal, polymeric protein, metal based, and iron oxide NPs have emerged as top-notcher. In this review, our discussion is mainly focused on the application of metal NPs.

\subsubsection{Silver NPs (AgNPs)}

Silver NPs are considered ideal because of their unique properties like catalytic activity and stability. They also contain anti-viral, anti-bacterial, and anti-fungal properties. One of the applications of AgNPs is used in the antibacterial nanodevices, because of its $\mathrm{Ag}^{+}$ion effect. They can be positively used as anti-cancer agents due to their anti-proliferative effect and ability to induce cell death [212]. AgNPs can be loaded/coated to reduce their toxicity and improve their biological retention time which allows specific targeting of cancerous cells. AgNPs from Andrographis echioides have been shown to inhibit the growth of MCF-2 cells and are widely used in human breast adenocarcinoma cell lines [213]. The viability of tumor cells declines with increase in AgNPs concentration. Allium sativum AgNPs have shown positive outcome in gastrointestinal carcinoma [214].

\subsubsection{Gold NPs (AuNPs)}

Gold NPs have anti-cancer properties and induce oxidative stress. They absorb photons and convert those incident photons to heat that destroys cancerous cells. Cationic gold NPs ( $2 \mathrm{~nm}$ diameter) are toxic at some dose [215]. Gold NPs exist in non-oxidized state. Smaller NPs had less protein-to-protein ratio as compared to larger ones. Reports show that gold NPs treated with Hela cervical carcinoma demonstrated increased reactive oxygen species (ROS), leading to oxidation of lipid, proteins, and other several molecules [216]. AuNPs of $10 \mathrm{~nm}$ size were widely distributed in organs whereas 50-250 nm (large) NPs were found to be distributed in liver, spleen, and blood when intravenously injected.

\subsubsection{Iron Oxide NPs}

Iron oxide NPs size lies between 1 and $100 \mathrm{~nm}$ in diameter. Their two main forms are magnetite $\left(\mathrm{Fe}_{2} \mathrm{O}_{3}\right)$ and maghemite $\left(\gamma-\mathrm{Fe}_{2} \mathrm{O}_{3}\right)$. Iron oxide NPs were synthesized by the process of precipitation in isobutanol (acting as surfactant) along with ammonium hydroxide and sodium hydroxide [217]. Iron oxide NPs are unstable in aqueous media without any surface coating; they aggregate and precipitate in vivo. The aggregates that are formed by unstable iron NPs inside the blood are sequestered by macrophages. Iron oxide NPs must be coated with different moieties to minimize the aggregation in certain conditions. Iron oxide magnetic NPs have many applications in anti-cancer strategy called hyperthermia; they destroy tissues nearby by generating heat. Iron oxide NPs have many properties like high solubility, stability, distribution, biocompatibility, and prolonged circulation time [218]. To increase the in vivo tumor imaging sensitivity, it is important to deliver large concentration of NPs in both tumor cells and in tumor mass. In a study, it was found that iron oxide NPs cause significant cellular morphological modifications, inducing apoptosis and necrosis in MCF-7 cell lines [219].

However, there is a need for restraint on the use and applications of these nanomaterials as drugs. A detailed understanding on possible hazards and toxicological impact of NPs on the environment as well as human health is needed prior to its application. Understanding the mechanisms of NPs access into the body, their function at cellular level, and their influences on public health is the call of the hour. Nanomaterial's characterization and understanding their surface functionality inside living systems are critical to understand their possible toxicological effects. All these parameters need more detailed studies before the approval of nanomaterial-based drugs for human usage. 


\subsection{Wastewater Treatment Process}

The increase in population growth rate, industrialization, and excessive use of chemicals has contaminated the aquatic environment by releasing wastewater to the environment. The water from natural resources is not suitable for consumption due to the presence of organic (dyes, pesticides, surfactants, etc.), inorganic (fluoride, arsenic, copper, mercury, etc.), biological (algae, bacteria, viruses, etc.), and radiological contaminants (cesium, plutonium, uranium, etc.) $[220,221]$. Figure $6 \mathrm{~A}$ depicts some of the common contaminants found in water. Several techniques such as physical, chemical, and biological have been adopted for the treatment of wastewater. However, search for new efficient technologies to improve water purification at low-cost is the current research focus. Currently, nanotechnology provides a new strategy for the removal of contaminants from wastewater with high efficiency. Several approaches have been developed in combination with various NPs for the successful removal of contaminants from wastewater as shown in Figure 6B.

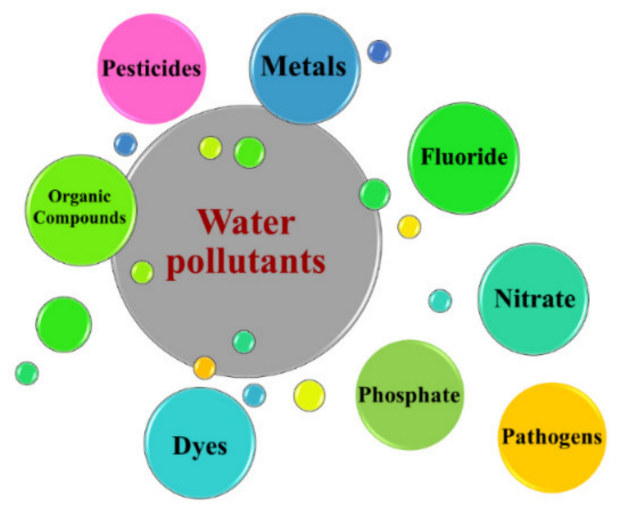

(A)

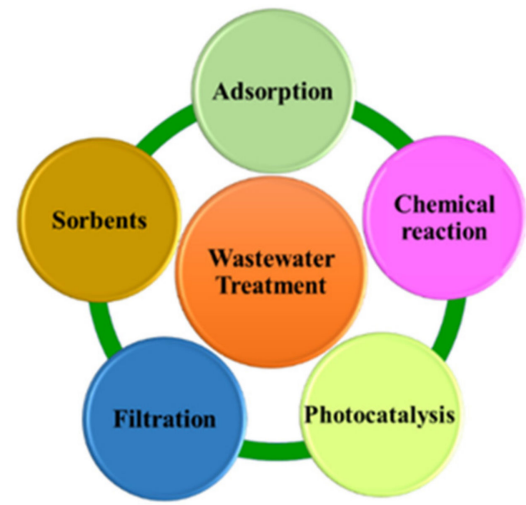

(B)

Figure 6. Common pollutants found in water and the treatment processes. (A) Common pollutants present in water. (B) Treatment approaches used for wastewater using nanoparticles.

The adsorption process is defined as the attachment of gaseous or liquid molecules over the surface of the solid and forms a layer or film of molecules. This process is mainly limited to the surface of the adsorbent where the adsorbate accumulates. The adsorption process could be physisorption or chemisorption depending upon the nature of bonding between the adsorbate and adsorbent i.e., van der Waals forces, covalent bonding, or electrostatic attraction. Adsorption is the most commonly used technique for the removal of contaminants from water due to its low-cost, easy operation, and absence of secondary pollutants formation [146]. Due to the development of nanotechnology and its wide applications in the past few decades, several nanostructured materials have been explored as adsorbent for their potential application in the treatment of industrial effluents, surface water, groundwater, and drinking water [222,223]. Nanoadsorbents exhibit higher efficiency and faster adsorption rate compared to the conventional adsorbent due to their small size, high porosity, and large active surface area [224]. Additionally, these nanoadsorbents show high reactivity and catalytic efficiency. Nanomaterials such as carbon nanotubes $(\mathrm{CNTs})$, ferric oxide $\left(\mathrm{Fe}_{3} \mathrm{O}_{4}\right)$, graphene, titanium oxide $\left(\mathrm{TiO}_{2}\right)$, manganese oxide $\left(\mathrm{MnO}_{2}\right)$, zinc oxide $(\mathrm{ZnO})$, and magnesium oxide $(\mathrm{MgO})$ are successfully used as adsorbent for the removal of contaminants such as heavy metals, azo dyes, etc. from the water $[223,225]$. Several nanosized metal oxide adsorbents including ferric oxide, aluminum oxides, manganese oxides, titanium oxides, magnesium oxides, and cerium oxides are proved to be promising for the removal of pollutants from water [226,227]. Furthermore, different metal oxide NPs are superparamagnetic which allows the easy separation of these adsorbents from the reaction mixture with the application of an external magnetic field. Das et al. [228] reported the removal of methylene blue dye, $\mathrm{Cu}(\mathrm{II})$, and 
$\mathrm{Co}$ (II) from aqueous solution using green synthesized magnetite NPs from crude latex of Jatropha curcas and leaf extract of Cinnamomum tamala. The removal of Cd(II) from contaminated solution was studied by using silver NPs prepared using leaf extract of Ficus tree (Ficus Benjamina) [229]. In a similar type of study, the removal of cadmium ions from contaminated solution was carried out using iron oxide NPs prepared by co-precipitation method with tangerine peel extract [230]. Maximum removal efficiency $90 \%$ achieved at $\mathrm{pH} 4.0$ and adsorbent dose of $0.4 \mathrm{~g} / 100 \mathrm{~mL}$. Zinc oxide NPs synthesized from Aloe vera and Cassava starch used as copper ion adsorbent and higher removal efficiency was observed for Aloe vera synthesized NPs with the increase in adsorbate concentration [231]. These nanoadsorbents demonstrate remarkable efficiency in the removal of pollutants from wastewater; however, the toxicity of residual NPs in the wastewater and reduced potential activity due to the use of a huge number of NPs in the treatment process to minimize the process duration are the major shortcomings of this process [232].

Filtration of contaminated water or wastewater through membranes is another way to remove the pollutants from the water. Nanofiltration is efficient and effective for the removal of different types of contaminants (organic, heavy metals, pathogens, etc.) from wastewater, and the removal efficiency is mainly dependent upon the pore size and charge characteristics of the membrane [233]. Numerous studies have focused on the development and use of a composite membrane, prepared by the introduction of NPs into the polymeric or inorganic membranes for the treatment of water. The incorporation of metal oxide NPs like silica [234], alumina [235,236], zeolite [237], and $\mathrm{TiO}_{2}[161,238]$ into polymeric membrane improved the membrane hydrophobicity and permeability. In addition to this, the incorporation of antimicrobial NPs like silver NPs into membrane matrix hinders bacterial attachment and biofilm formation $[239,240]$.

Metal NPs are extensively used as nano-catalysts in water treatment due to their high surface-to-volume ratio and surface catalytic activity. These nano-catalysts improve the quality of water by degrading various contaminants, viz. dyes, pesticides, herbicides, polychlorinated biphenyls, nitro aromatics, etc. [241]. Various kinds of nano-catalysts such as electrocatalysts, photocatalysts, and Fenton-based catalysts are employed in the wastewater treatment process [220]. The mechanism behind photocatalysis is the photoexcitation of electron present in the catalysts. The light irradiation causes the generation of holes $\left(\mathrm{h}^{+}\right)$ and exited electrons $\left(\mathrm{e}^{-}\right)$. Further, the generated holes $\left(\mathrm{h}^{+}\right)$are trapped by water molecules $\left(\mathrm{H}_{2} \mathrm{O}\right)$ in aqueous media that subsequently form the hydroxyl radicals $\left({ }^{\bullet} \mathrm{OH}\right)$ [242]. These hydroxyl radicals are highly reactive and powerful oxidizing agents which oxidize the organic pollutants leading to the formation of water and gaseous degradation products [242]. Numerous studies reported photocatalytic activity of green synthesized Ag, Au, Pt, and Pd NPs in degradation of different dyes [63,243-247]. Additionally, various metal oxide NPs such as $\mathrm{ZnO}, \mathrm{CuO}, \mathrm{FeO}, \mathrm{SnO}_{2}, \mathrm{TiO}_{2}, \mathrm{NiO}, \mathrm{CeO}_{2}$, etc. exhibited excellent photocatalytic activity for the degradation of different organic pollutants [248].

\subsection{Antimicrobial Activity}

In the past decade, application of nanomaterials to control microbial proliferation has garnered much interest from scientists worldwide $[249,250]$. The increase in resistance of microorganisms to antimicrobial agents, including antibiotics, has led to a spike in healthrelated complications. A vast body of work has revealed that by combining three forces of material science, nanotechnology, and the inherent antimicrobial activity possessed by certain metals, innovative applications for metal NPs can be identified [251]. Previous studies have reported that metal and their counterpart metal oxide nanoparticles have displayed toxicity towards numerous microorganisms $[209,250]$. These NPs may be used successfully to stop the growth of various bacterial species.

The surge in development of multi-drug resistant pathogens is presenting itself as a grave problem to public health, and thus, several studies have been conducted at improving the prevailing antimicrobial treatments [251]. It has been identified that approximately $70 \%$ of bacterial infections have developed resistance to one or more of the first- and second-line 
drugs that have been traditionally used to treat the infection [252]. The development of resistance in bacteria to commonly used chemical antibacterial agents may occur due to the lengthy production-consumption cycle, thus leading to reduction in efficacy. Moreover, the rampant use of poor quality or over-the-counter medicines in developing countries has led to a steep rise in antimicrobial resistance [253]. The need of the hour is to speed up the research and development and the synthesis of novel antimicrobial agents which are effective as well. NPs as antibacterial agents have turned out to be an emerging technology against this challenge, which have the ability to establish an effective nanostructure, which may be used to deliver the antibacterial agents, hence targeting the bacterial growth locally and more efficiently. In addition, nanoparticles have proved to have the potency that it leaves the pathogens with little device to develop resistance against them. Most of the available metal oxide NPs have zero toxicity for mammalian cells at the concentrations that have been used to kill bacterial cells, which in turn is an advantage for using them at a larger scale [254].

Metals like gold $(\mathrm{Au})$, silver $(\mathrm{Ag})$, titanium $(\mathrm{Ti})$, copper $(\mathrm{Cu})$, and zinc $(\mathrm{Zn})$ are known to have their own properties and potency and display differential activity against microorganisms. This information has been understood and utilized across various cultures for centuries [255]. Numerous kinds of nanoparticles and their derivatives have been explored for their potential antimicrobial effects against several microorganisms. Metal nanoparticles such as gold $(\mathrm{Au})$, silver $(\mathrm{Ag})$, silicon $(\mathrm{Si})$, silver oxide $\left(\mathrm{Ag}_{2} \mathrm{O}\right)$, titanium dioxide $\left(\mathrm{TiO}_{2}\right)$, zinc oxide $(\mathrm{ZnO})$, copper oxide $(\mathrm{CuO})$, calcium oxide $(\mathrm{CaO})$, and magnesium oxide $(\mathrm{MgO})$ have been recognized to display antimicrobial activity. In vitro studies have suggested that metal nanoparticles have the potential to inhibit several microbial species, like Escherichia coli, Staphylococcus aureus, Bacillus subtilis, Pseudomonas aeruginosa, etc. [256-265].

The type of materials used in formulating the nanoparticles along with their particle size are the two most significant parameters, which can have an effect on the effectiveness of antimicrobial activity. It is well established that nanoparticles tend to possess different characteristics when compared to the same material having significantly greater dimensions. This is because the surface to volume ratio of the NPs considerably increases with a decrease in the particle size [266]. Certainly, in dimensions of nanoscale, the fraction of the molecule surface noticeably increases, which in turn can lead in improvement of some of the properties of the particles. For example, it may be mass transfer, heat treatment, catalytic activity, or the dissolution rate [267]. Additionally, the morphology and physicochemical properties of NPs have also been demonstrated to wield an effect on their level of germicidal activities. Literature survey has pointed that the particle size plays a role as vital parameter that can determine the effectiveness of antimicrobial activity of the metal nanoparticles $[268,269]$. The use of combination therapy with metal nanoparticles has the potential to be a strategy that can help tide over the emergence of bacterial resistance to multiple antibacterial agents $[270,271]$. More studies need to be developed to understand if green synthesized nanoparticles have better efficacy over traditionally synthesized nanoparticles. Current studies have displayed the same level of antimicrobial effects $[272,273]$.

The shape of nanoparticles also has major influence on their antimicrobial effects [268]. Several research studies have investigated these shape-dependent characteristics of nanoparticles. A study described antibacterial activity of Ag NPs in three dissimilar shapes, namely, spherical, rod-shaped, and truncated triangular. It came to the conclusion that the truncated triangular NPs were more inclined to be reactive owing to their high atom density surfaces and consequently displayed greater antimicrobial activity [274]. In another study, the size and shape-dependent antimicrobial activity of fluorescent Ag nanoparticles (1-5 nm) was studied against some selected Gram-positive and Gram-negative bacteria [275]. They highlighted that the size and shape of the particles generated an effect on its activity. These investigations reported that the smaller the particles size, the easier they breach the cell wall exhibiting heightened antimicrobial activity. Furthermore, the authors proposed that these AgNPs could be used for multiple diverse procedures such as wound dressing, 
biofilms, bio-adhesives, and coating of certain biomedical materials. It was also found that antimicrobial property of $\mathrm{TiO}_{2}$ is related to the size, shape, and structure of its crystal [252]. It is proposed in this particular study that the generation of ROS, ultimately leading to development of oxidative stress in the cells, may be a significant mechanism for $\mathrm{TiO}_{2}$ nanoparticles to show its germicidal activity. It is well known then that ROS has the capability to cause site specific DNA damage, ultimately leading to the death of the cell.

The exact mechanisms in which nanometals present the antibacterial effect are still an area of active investigation. However, two common options have been proposed in this aspect. Firstly, toxicity associated with free metal ions can arise due to the dissolution of the metals from the surface of NPs. Secondly, oxidative stress could be triggered through the production of reactive oxygen species (ROS) on the surface of the NPs. Based on literature review, there are some intrinsic factors that can have an influence on the ability of nanomaterials in reducing the number of cells or completely eliminating the cells [255].

NPs are a promising technology, and owing to its vast application, understanding nanotoxicity and its consequences is of utmost importance. For decades, the pharmaceutical industry has used NPs as a tool to reduce toxicity and side effects of drugs [276]; nonetheless, one needs to be careful when using NPs, as certain safety concerns still exist. Several reports have identified damage to neurological and respiratory organs issues in the circulatory system. In addition, other yet unknown toxic effects of NPs are few of the foremost apprehensions in using NPs as part of a systemic therapy. Undeniably, numerous NPs seem non-toxic, and a few of them are reduced to having non-toxic properties, which ultimately has beneficial effects on health [209,277-279]. Nevertheless, further studies need to be executed focusing on minimizing the toxicity of metal and metal oxide NPs, that will eventually be applied in therapy as a proper substitute to disinfectants and antibiotics especially in biomedical applications. Moreover, current research should make the application of antimicrobial activity of NPs in eradication of microbial infections as one of their priorities.

\section{Toxicity of Metal Nanoparticles}

NPs have wide applicability in different sectors such as electronics, agriculture, chemicals, pharmaceutical, food, etc. due to their unique physicochemical properties [280]. The most commonly used NPs by various sectors include metal oxide NPs such as silicon oxide $\left(\mathrm{SiO}_{2}\right)$, titanium dioxide $\left(\mathrm{TiO}_{2}\right)$, zinc oxide $(\mathrm{ZnO})$, aluminum hydroxide $\left[\mathrm{Al}(\mathrm{OH})_{3}\right]$, cerium oxide $(\mathrm{CeO})$, copper oxide $(\mathrm{CuO})$, silver $(\mathrm{Ag})$, nanoclays, carbon nanotubes, nanocellulose, etc. [281,282]. However, massive release of NPs into the environment (air, water, and soil) by various industries is resulting in production of nanowaste and proving to be dangerous for the living organisms and causing threat to ecosystem balance. Various characteristics of NPs affecting their toxicity are size, nature, reactivity, mobility, stability, surface chemistry, aggregation, storage time, etc. NPs cause adverse consequences on human health and animals. Use of NPs has intensified the risk of various diseases in humans such as diabetes, cancer, bronchial asthma, allergies, inflammation, etc. [3]. The animal reproductive system has also been shown to be affected due to toxicity of various NPs such as $\mathrm{Au}, \mathrm{TiO}_{2}$, etc. $[283,284]$. NPs enter the animal body through ingestion and inhalation and get absorbed by the cells through the processes of phagocytosis and endocytosis and induce the generation of reactive oxygen species (ROS), ultimately resulting into lipid peroxidation, mitochondrial damage, etc. Different $\mathrm{NPs}$ such as $\mathrm{Ag}, \mathrm{Cu}, \mathrm{ZnO}, \mathrm{Ni}$, etc. have also reduced the enzymatic activity of various microorganisms. In addition, excessive production of NPs is also affecting the food web of the ecosystem [285]. Toxicity effects of NPs over plants, animals, and microorganisms are shown in Figure 7. 


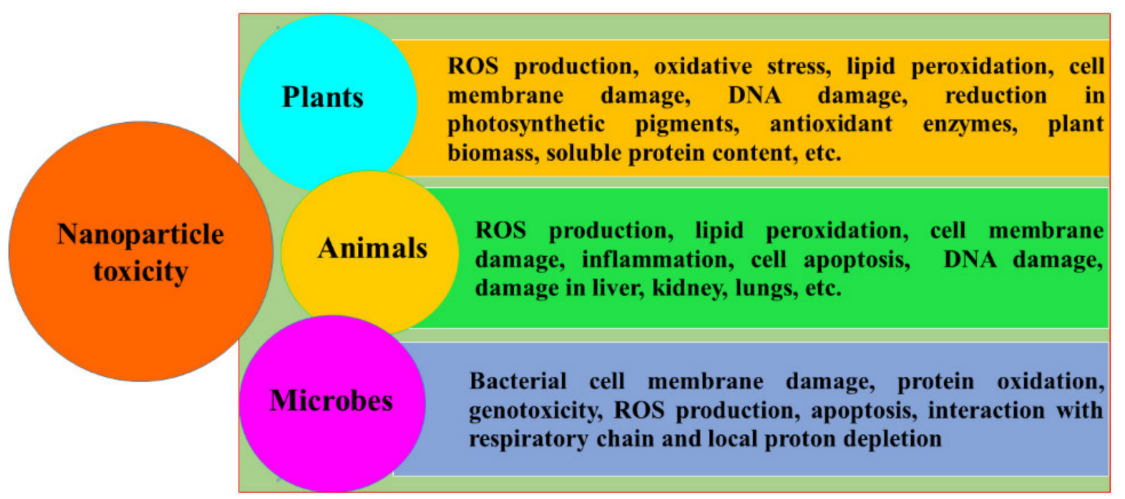

Figure 7. Toxicity effects of NPs on microbes, plants, and animals.

\subsection{Impact of Nanoparticle Toxicity on Plants}

Plants are of high fundamental significance as they perform photosynthesis and release oxygen in the atmosphere. As all the plant parts (roots, shoots, and leaves) are in direct contact with environmental matrices (air, water, and soil), they may get affected more by the NPs contamination as compared to the other living beings. NPs present in the atmosphere can enter into the plant body through the stomatal openings on leaves [286], while those present in soil and water can be selectively up taken by the plant roots [287].

NPs proved to be toxic to plants and hamper their growth and development. The toxicity in plants is mainly due to ROS production, causing lipid peroxidation and ultimately leading to DNA damage, reduction in photosynthetic pigments, plant biomass, soluble protein content reduction, etc. [288]. However, plants have a defensive system against oxidative stress in the form of enzymatic and non-enzymatic antioxidants, which may become inefficient under higher oxygen concentrations [289].

Assessment of NPs Phytotoxic and Genotoxic Effects on the Plants

While phytotoxic effects of NPs on the plant can be assessed by analyzing morphological and physiological changes, genotoxicity can be observed by observing DNA damage in the plant cell. By evaluating various physiological parameters such as germination, biomass production, leaf number, photosynthetic ability, root and shoot length, etc., phytotoxicity levels of NPs on the plants can be assessed. To observe genotoxic effects on the plant, assessment of cytology of plant roots for the determination of mitotic index, chromosomal abnormalities, etc. is the simplest approach [290].

$\mathrm{SiO}_{2}$ NPs are among the top metal oxide NPs produced by various industries such as cosmetics, pharmaceuticals, food, etc. due to their worldwide demand. Positive effects of $\mathrm{SiO}_{2}$ NPs on various plants such as Oryza sativa, $V$. faba, S. lycopersicum, Medicago sativa, etc. have been shown in different studies [291-294]. Toxic effects of $\mathrm{SiO}_{2} \mathrm{NPs}$ on plants have been investigated by Slomberg and Schoenfisch [295] in Arabidopsis thaliana, Karimi and Mohsenzadeh [296] in Triticum aestivum, and Silva and Monteiro [297] in A. cepa, etc. Regarding $\mathrm{TiO}_{2}$ NPs, negative effects have been shown in Z. mays and Vicia narbonensis [298], $V$. narbonensis [299], V. faba [300,301], etc. ZnO NPs are majorly used in agriculture sector (as pesticides, fertilizers, etc.) [302].

In green algae, Chlorella vulgaris and Dunaliella tertiolecta, AgNPs proved to be inhibitory for their growth and displayed higher ROS production and lipid peroxidation [303]. AgNPs also proved to be toxic for the growth and development of green algae, Pithophora oedogonia and Chara vulgaris [304].

\subsection{Toxicity of Nanoparticle-Based Drugs}

The commercial applications of NPs as therapeutics for treatment of diseases is a double-edged sword. Even though many studies are being done worldwide to analyze the toxic effects of NM exposure, the possible mechanism of NMs interactions with biological systems and their consequences are still unknown. Research has shown that NPs can travel 
through the bloodstream and easily cross membrane barriers. This in turn can adversely affect tissues and organs at molecular and cellular levels [305]. NPs have demonstrated the capacity to cross the blood-brain barrier (BBB) and gain access to the brain [306]. Small size, large surface area to mass ratio (SA/MR), and surface characteristics determine nanoparticle's interaction with biological milieu and the resultant toxic effects that ensue. The unique nature of the NMs allow them to easily pass-through cell and tissue membranes and cellular compartments to cause cellular damage. The large SA/MR of NPs also remains open for active chemical interactions with cellular macromolecules. Increase in surface area of the identical chemical further enhances adsorption properties, surface reactivity, and potential toxicity [305].

NPs have the tendency to translocate across cell barriers from the entry point i.e., the respiratory tract to secondary organs, reach the cells by various mechanisms and start interacting with subcellular structures. These properties make NPs uniquely suitable for therapeutic and diagnostic uses. NPs are transported neuronally, involving retrograde and anterograde movement in axons and dendrites as well as perineural translocations. The target organs such as the central nervous system (CNS), however, bear the brunt of potential adverse effects (e.g., oxidative stress) [306]. The size of NPs has an important role in renal clearance and in avoiding immune activation, enhancing the efficacy and circulation time of the drug inside systemic circulation [209]. In case of nickel NPs, small particle sizes (less than $200 \mathrm{~nm}$ ) are preferable for entering into epithelial cells, whereas larger NPs are phagocytosed by macrophages present. Another issue is surface charge which restraints the fate of NPs. Positively charged surface NPs with amorphous nature do not enter inside the cells, whereas, negatively charged crystalline nickel sulphide and sub-sulphide particles can enter cells by phagocytosis. Inhalation of $\mathrm{MnO}_{2} \mathrm{NPs}$ leads to the formation of ROS causing oxidative stress in brain [210].

Silver NPs of different sizes, i.e., 20 or $40 \mathrm{~nm}$ (Ag20Pep and Ag40Pep) were analyzed in THP-1-derived human macrophages through their cellular uptake. Results demonstrated a majority of the AgNPs spread throughout the cells. Formation of protein carbonyls or induction of heme oxygenase I are some of the associated responses due to oxidative stress are also observed. The charged Au NPs sized $15 \mathrm{~nm}$ cause cell death by apoptosis, whereas neutral Au NPs cause necrosis in HaCaT (human epidermal keratinocyte) cell lines [307]. Several NPs can penetrate inside the nuclear envelop, and they play an important role in inducing genotoxicity. Silver NPs have been found to be more toxic than gold NPs. $\mathrm{TiO}_{2} \mathrm{NPs}$ are considered as biological inert material in vitro and in vivo, while $\mathrm{TiO}_{2} \mathrm{NPs}$ larger than $15 \mu \mathrm{m}$ are highly toxic, generating $\mathrm{ROS}$. $\mathrm{TiO}_{2}$ is toxic to PC12 cells [308]. It was reported that toxicity of NPs increases with increasing surface charges, i.e., lower positive charge NPs have less electrostatic interaction with the cells. Positive ZnO NPs have more cytotoxic effect in A549 cells as compared to same sized and shaped negatively charged $\mathrm{ZnO}$ [309]. Rod shaped $\mathrm{Fe}_{2} \mathrm{O}_{3}$ NPs produce high cytotoxic responses compared to spherical $\mathrm{Fe}_{2} \mathrm{O}_{3}$ NPs in RAW 264.7 (murine macrophage) cell lines [310]. Rod-shaped $\mathrm{CeO}_{2} \mathrm{NPs}$ cause more toxic effects and produce LDH and necrosis factor- $\alpha$ in RAW 264.7 cells [209]. NPs cytotoxicity depends on assay, cell line, and physical and chemical properties. Copper oxide NPs have been found to produce toxic side effects in liver and kidneys when examined on lab animals; after oral administration and interaction with gastric juice, they form reactive ionic copper. It was reported that silver NPs and iron oxide NPs can penetrate and cross the blood-brain barrier [306]. Iron oxide has the capacity to accumulate inside liver, spleen, lungs, and brain and has the capacity to cross the BBB after inhalation [305]. Iron oxide shows less cytotoxic effects at high concentration $(300-500 \mathrm{~kg} / \mathrm{mL}, 6 \mathrm{~h})$ than in low concentration $(25-200 \mu \mathrm{g} / \mathrm{mL})$. At low concentration, it generates Reactive oxygen species (ROS), DNA damage, and causes lipid peroxidation. Silica based NPs of size $70 \mathrm{~nm}$ at $30 \mathrm{mg} / \mathrm{kg}$ concentration have been found to alter biochemical parameters [210]. Hence, a number of studies show evidence of NPs causing DNA and membrane damage, protein misfolding, and mitochondrial damage. 
In a clinical scenario, several factors need to be addressed, viz., bioavailability, adverse reactions, cellular interactions, biodistribution, biodegradation, etc. The successful clinical translation of nanomedicines is therefore a long and onerous process of weighing the benefits against risks of toxicity involved. Scientists must proceed with caution and refrain from premature launch of nanomedicines without assessing the adverse effects involved.

Compared to physio-chemical methods, biologically synthesized NPs have been proved to be non-toxic/less toxic due to non-use of external stabilizing agents and hazardous chemicals/solvents during the synthesis process. Hasan et al. [164] compared the morphological, physiological, and biochemical responses of biologically and chemically synthesized iron oxide NPs in Zea mays. The biological synthesized FeO NPs promoted better plant growth as compared to the chemically derived NPs. The chemically synthesized NPs proved toxic and hampered the plant growth even at lower concentrations. In a similar kind of study, Anna et al. [311] observed better growth of green algae P. kessleri while using biologically synthesized NPs compared to chemical synthesized NPs.

\section{Major Challenges and Future Perspective}

In the recent past, research on NPs and their potential applications have progressed by leaps and bounds. Numerous studies have reported the green synthesis of metallic NPs using various biological sources such as plants, bacteria, fungi, and yeast. However, several challenges persist, which limit its large-scale production and consequent applications. Some of the major challenges observed during the synthesis are summarized below:

- Detailed optimization studies on reactants (plant extract, microorganism inoculum, fermentation medium composition, etc.) and process parameters (temperature, $\mathrm{pH}$, rotational speed, etc.) are required to control the size and shape of the NPs.

- Studies also need to be focused on enhancing various physicochemical characteristics of NPs for specific applications.

- The involvement of each metabolite of plant extract and cellular components of microorganism in the synthesis of NPs should be completely analyzed.

- Scale-up of NPs production for commercial purposes using green synthesis methods needs to be prioritized.

- Improvement of NPs yield and stability with reduced reaction time is needed by optimizing various reaction parameters.

Addressing these challenges could make the green synthesis methods cost-effective and comparable to the conventional methods for the large-scale production of NPs. Additionally, the separation and purification of NPs from the reaction mixture is another important aspect that need to be explored. A detailed toxicological study of the NPs on plants and animals is necessary for expanding its application in diverse fields. In addition to wild type strains, genetically modified microorganisms with the ability to produce greater quantity of enzymes, proteins, and biomolecules could further enhance the biosynthesis as well as the stabilization of NPs. Further, enhancement of metal accumulation capacity and tolerance of genetically modified microorganisms could provide a futuristic approach for the production and application of metal NPs using the green synthesis method.

\section{Conclusions}

The present review focuses on the green synthesis of metal NPs derived from plants and microorganism and their applications. Green synthesis methods provide a clean, non-toxic, and eco-friendly approach for the synthesis of metal NPs compared to other conventional techniques like physical and chemical methods. A wide range of plant materials including leave extract, fruit extract, seed, fruit, bark, etc. and microorganism such as bacteria, fungi, actinomycetes, etc. have shown potential for synthesis of various metal and metal oxide NPs (viz., $\mathrm{Au}, \mathrm{Ag}, \mathrm{Pt}, \mathrm{Pd}, \mathrm{Ni}, \mathrm{Se}, \mathrm{Cu}, \mathrm{CuO}$, and $\mathrm{TiO}_{2}$ ). The size and shape of NPs and the reaction rate strongly depend on various experimental parameters such as reaction time, reactant concentration, $\mathrm{pH}$, temperature, aeration, salt concentration, etc. Different characterization techniques such as UV-VIS spectroscopy, FTIR, XRD, SEM, 
TEM, EDX, and AFM have been used to determine the shape, size, and morphology of biosynthesized NPs. However, in terms of translational research, several factors, viz., bioavailability, adverse reactions, cellular interactions, biodistribution, and biodegradation, need to be addressed. The accumulation of these NPs in the environment and their uptake by biological systems can lead to disastrous consequences as a number of studies show evidence of NPs causing DNA and membrane damage, protein misfolding, and mitochondrial damage. Although numerous studies reported the biological synthesis of metal NPs, a thorough investigation is the need of the hour for widening their applications and successful commercialization.

Author Contributions: Conceptualization, P.K.D.; writing—original draft preparation, P.K.D., J.K., A.K.D., S.S. (Soumi Sadhu), S.S. (Sunita Sharma), S.S. (Swati Singh); writing-review and editing, P.K.D., J.K., A.K.D., S.S. (Soumi Sadhu), S.S. (Sunita Sharma), S.S. (Swati Singh), P.K.G., B.S.K. All authors have read and agreed to the published version of the manuscript.

Funding: This research received no external funding.

Data Availability Statement: Not applicable.

Conflicts of Interest: The authors declare no conflict of interest.

\section{References}

1. Sahoo, M.; Vishwakarma, S.; Panigrahi, C.; Kumar, J. Nanotechnology: Current applications and future scope in food. Food Front. 2021, 2, 3-22. [CrossRef]

2. Maurer-Jones, M.A.; Gunsolus, I.L.; Murphy, C.J.; Haynes, C.L. Toxicity of engineered nanoparticles in the environment. Anal. Chem. 2013, 85, 3036-3049. [CrossRef] [PubMed]

3. Pandey, R.K.; Prajapati, V.K. Molecular and immunological toxic effects of nanoparticles. Int. J. Biol. Macromol. 2018, 107, 1278-1293. [CrossRef] [PubMed]

4. Yu, H.; Park, J.Y.; Kwon, C.W.; Hong, S.C.; Park, K.M.; Chang, P.S. An overview of nanotechnology in food science: Preparative methods, practical applications, and safety. J. Chem. 2018, 2018, 5427978. [CrossRef]

5. Vance, M.E.; Kuiken, T.; Vejerano, E.P.; McGinnis, S.P.; Hochella, M.F., Jr.; Rejeski, D.; Hull, M.S. Nanotechnology in the real world: Redeveloping the nanomaterial consumer products inventory. Beilstein J. Nanotechnol. 2015, 6, 1769-1780. [CrossRef]

6. Das, R.K.; Pachapur, V.L.; Lonappan, L.; Naghdi, M.; Pulicharla, R.; Maiti, S.; Cledon, M.; Dalila, L.M.A.; Sarma, S.J.; Brar, S.K. Biological synthesis of metallic nanoparticles: Plants, animals and microbial aspects. Nanotechnol. Environ. Eng. 2017, 2, 1-21. [CrossRef]

7. Thakkar, K.N.; Mhatre, S.S.; Parikh, R.Y. Biological synthesis of metallic nanoparticles. Nanomedicine 2010, 6, 257-262. [CrossRef]

8. Iravani, S.; Korbekandi, H.; Mirmohammadi, S.V.; Zolfaghari, B. Synthesis of silver nanoparticles: Chemical, physical and biological methods. Res. Pharm. Sci. 2014, 9, 385. [PubMed]

9. Banne, S.V.; Patil, M.S.; Kulkarni, R.M.; Patil, S.J. Synthesis and characterization of silver nano particles for EDM applications. Mater. Today 2017, 4, 12054-12060. [CrossRef]

10. Tan, Y.; Dai, X.; Li, Y.; Zhu, D. Preparation of gold, platinum, palladium and silver nanoparticles by the reduction of their salts with a weak reductant-potassium bitartrate. J. Mater. Chem. 2003, 13, 1069-1075. [CrossRef]

11. Norris, C.B.; Joseph, P.R.; Mackiewicz, M.R.; Reed, S.M. Minimizing formaldehyde use in the synthesis of gold- silver coreshell nanoparticles. Chem. Mater. 2010, 22, 3637-3645. [CrossRef]

12. Mallick, K.; Witcomb, M.J.; Scurrell, M.S. Polymer stabilized silver nanoparticles: A photochemical synthesis route. J. Mater. Sci. 2004, 39, 4459-4463. [CrossRef]

13. Eluri, R.; Paul, B. Synthesis of nickel nanoparticles by hydrazine reduction: Mechanistic study and continuous flow synthesis. J. Nanopart. Res. 2012, 14, 1-14. [CrossRef]

14. Akbarzadeh, R.; Dehghani, H. Sodium-dodecyl-sulphate-assisted synthesis of Ni nanoparticles: Electrochemical properties. Bull. Mater. Sci. 2017, 40, 1361-1369. [CrossRef]

15. Pandey, G.; Singh, S.; Hitkari, G. Synthesis and characterization of polyvinyl pyrrolidone (PVP)-coated Fe $\mathrm{O}_{4}$ nanoparticles by chemical co-precipitation method and removal of Congo red dye by adsorption process. Int. Nano Lett. 2018, 8 , 111-121. [CrossRef]

16. Gupta, R.; Xie, H. Nanoparticles in daily life: Applications, toxicity and regulations. J. Environ. Pathol. Toxicol. Oncol. 2018, 37, 209-230. [CrossRef]

17. Hua, S.; De Matos, M.B.; Metselaar, J.M.; Storm, G. Current trends and challenges in the clinical translation of nanoparticulate nanomedicines: Pathways for translational development and commercialization. Front. Pharmacol. 2018, 9, 790. [CrossRef]

18. Sriramulu, M.; Shanmugam, S.; Ponnusamy, V.K. Agaricus bisporus mediated biosynthesis of copper nanoparticles and its biological effects: An in-vitro study. Colloid Interface Sci. Commun. 2020, 35, 100254. [CrossRef] 
19. Kuppusamy, P.; Yusoff, M.M.; Maniam, G.P.; Govindan, N. Biosynthesis of metallic nanoparticles using plant derivatives and their new avenues in pharmacological applications-An updated report. Saudi Pharm. J. 2016, 24, 473-484. [CrossRef]

20. Mittal, A.K.; Chisti, Y.; Banerjee, U.C. Synthesis of metallic nanoparticles using plant extracts. Biotechnol. Adv. 2013, 31, 346-356. [CrossRef]

21. Narayanan, K.B.; Sakthivel, N. Green synthesis of biogenic metal nanoparticles by terrestrial and aquatic phototrophic and heterotrophic eukaryotes and biocompatible agents. Adv. Colloid Interfac. 2011, 169, 59-79. [CrossRef]

22. Nath, D.; Banerjee, P. Green nanotechnology_A new hope for medical biology. Environ. Toxicol. Pharmacol. 2013, 36, 997-1014. [CrossRef] [PubMed]

23. Gardea-Torresdey, J.L.; Parsons, J.G.; Gomez, E.; Peralta-Videa, J.; Troiani, H.E.; Santiago, P.; Yacaman, M.J. Formation and growth of Au nanoparticles inside live alfalfa plants. Nano Lett. 2002, 2, 397-401. [CrossRef]

24. Bali, R.; Harris, A.T. Biogenic synthesis of Au nanoparticles using vascular plants. Ind. Eng. Chem. Res. 2010, 49, 12762-12772. [CrossRef]

25. Mohamad, N.A.N.; Arham, N.A.; Jai, J.; Hadi, A. Plant extract as reducing agent in synthesis of metallic nanoparticles: A review. Adv. Mat. Res. 2014, 832, 350-355. [CrossRef]

26. Krishnaraj, C.; Muthukumaran, P.; Ramachandran, R.; Balakumaran, M.D.; Kalaichelvan, P.T. Acalypha indica Linn: Biogenic synthesis of silver and gold nanoparticles and their cytotoxic effects against MDA-MB-231, human breast cancer cells. Biotechnol. Rep. 2014, 4, 42-49. [CrossRef] [PubMed]

27. Dwivedi, A.D.; Gopal, K. Biosynthesis of silver and gold nanoparticles using Chenopodium album leaf extract. Colloids Surf. A 2010, 369, 27-33. [CrossRef]

28. Philip, D. Green synthesis of gold and silver nanoparticles using Hibiscus Rosa Sinensis. Phys. E 2010, 42, 1417-1424. [CrossRef]

29. Baghizadeh, A.; Ranjbar, S.; Gupta, V.K.; Asif, M.; Pourseyedi, S.; Karimi, M.J.; Mohammadinejad, R. Green synthesis of silver nanoparticles using seed extract of Calendula officinalis in liquid phase. J. Mol. Liq. 2015, 207, 159-163. [CrossRef]

30. Gurunathan, S.; Han, J.W.; Kwon, D.N.; Kim, J.H. Enhanced antibacterial and anti-biofilm activities of silver nanoparticles against Gram-negative and Gram-positive bacteria. Nanoscale Res. Lett. 2014, 9, 1-17. [CrossRef]

31. Pragathiswaran, C.; Violetmary, J.; Faritha, A.; Selvarani, K.; Nawas, P.M. Photocatalytic degradation, sensing of Cd ${ }^{2+}$ using silver nanoparticles synthesised from plant extract of Cissus quadrangularis and their microbial activity. Mater. Today Proc. 2021, 45, 3348-3356. [CrossRef]

32. Salih, T.A.; Hassan, K.T.; Majeed, S.R.; Ibraheem, I.J.; Hassan, O.M.; Obaid, A.S. In vitro scolicidal activity of synthesised silver nanoparticles from aqueous plant extract against Echinococcus granulosus. Biotechnol. Rep. 2020, 28, e00545. [CrossRef] [PubMed]

33. Dhar, S.A.; Chowdhury, R.A.; Das, S.; Nahian, M.K.; Islam, D.; Gafur, M.A. Plant-mediated green synthesis and characterization of silver nanoparticles using Phyllanthus emblica fruit extract. Mater. Today Proc. 2021, 42, 1867-1871. [CrossRef]

34. Chavan, R.R.; Bhinge, S.D.; Bhutkar, M.A.; Randive, D.S.; Wadkar, G.H.; Todkar, S.S.; Urade, M.N. Characterization, antioxidant, antimicrobial and cytotoxic activities of green synthesized silver and iron nanoparticles using alcoholic Blumea eriantha DC plant extract. Mater. Today Commun. 2020, 24, 101320. [CrossRef]

35. Kambale, E.K.; Nkanga, C.I.; Mutonkole, B.P.I.; Bapolisi, A.M.; Tassa, D.O.; Liesse, J.M.I.; Krause, R.W.; Memvanga, P.B. Green synthesis of antimicrobial silver nanoparticles using aqueous leaf extracts from three Congolese plant species (Brillantaisia patula, Crossopteryx febrifuga and Senna siamea). Heliyon 2020, 6, e04493. [CrossRef]

36. Vignesh, V.; Anbarasi, K.F.; Karthikeyeni, S.; Sathiyanarayanan, G.; Subramanian, P.; Thirumurugan, R. A superficial phytoassisted synthesis of silver nanoparticles and their assessment on hematological and biochemical parameters in Labeo rohita (Hamilton, 1822). Colloids Surf. A 2013, 439, 184-192. [CrossRef]

37. Vivek, R.; Thangam, R.; Muthuchelian, K.; Gunasekaran, P.; Kaveri, K.; Kannan, S. Green biosynthesis of silver nanoparticles from Annona squamosa leaf extract and its in vitro cytotoxic effect on MCF-7 cells. Process Biochem. 2012, 47, 2405-2410. [CrossRef]

38. Zhang, Y.; Cheng, X.; Zhang, Y.; Xue, X.; Fu, Y. Biosynthesis of silver nanoparticles at room temperature using aqueous aloe leaf extract and antibacterial properties. Colloids Surf. A 2013, 423, 63-68. [CrossRef]

39. Jagtap, U.B.; Bapat, V.A. Green synthesis of silver nanoparticles using Artocarpus heterophyllus Lam. seed extract and its antibacterial activity. Ind. Crops Prod. 2013, 46, 132-137. [CrossRef]

40. Vidhu, V.K.; Philip, D. Catalytic degradation of organic dyes using biosynthesized silver nanoparticles. Micron 2014, 56, 54-62. [CrossRef]

41. Suriyakalaa, U.; Antony, J.J.; Suganya, S.; Siva, D.; Sukirtha, R.; Kamalakkannan, S.; Pichiah, P.T.; Achiraman, S. Hepatocurative activity of biosynthesized silver nanoparticles fabricated using Andrographis paniculata. Colloids Surf. B 2013, 102, 189-194. [CrossRef]

42. Jeyaraj, M.; Rajesh, M.; Arun, R.; MubarakAli, D.; Sathishkumar, G.; Sivanandhan, G.; Dev, G.K.; Manickavasagam, M.; Premkumar, K.; Thajuddin, N.; et al. An investigation on the cytotoxicity and caspase-mediated apoptotic effect of biologically synthesized silver nanoparticles using Podophyllum hexandrum on human cervical carcinoma cells. Colloids Surf. B 2013, 102, 708-717. [CrossRef] [PubMed]

43. Mittal, A.K.; Bhaumik, J.; Kumar, S.; Banerjee, U.C. Biosynthesis of silver nanoparticles: Elucidation of prospective mechanism and therapeutic potential. J. Colloid Interface Sci. 2014, 415, 39-47. [CrossRef] [PubMed]

44. Adewale, O.B.; Egbeyemi, K.A.; Onwuelu, J.O.; Potts-Johnson, S.S.; Anadozie, S.O.; Fadaka, A.O.; Osukoya, O.A.; Aluko, B.T.; Johnson, J.; Obafemi, T.O.; et al. Biological synthesis of gold and silver nanoparticles using leaf extracts of Crassocephalum rubens and their comparative in vitro antioxidant activities. Heliyon 2020, 6, e05501. [CrossRef] 
45. Daisy, P.; Saipriya, K. Biochemical analysis of Cassia fistula aqueous extract and phytochemically synthesized gold nanoparticles as hypoglycemic treatment for diabetes mellitus. Int. J. Nanomed. 2012, 7, 1189. [CrossRef] [PubMed]

46. Thangamani, N.; Bhuvaneshwari, N. Green synthesis of gold nanoparticles using Simarouba glauca leaf extract and their biological activity of micro-organism. Chem. Phys. Lett. 2019, 732, 136587. [CrossRef]

47. Satpathy, S.; Patra, A.; Ahirwar, B.; Hussain, M.D. Process optimization for green synthesis of gold nanoparticles mediated by extract of Hygrophila spinosa T. Anders and their biological applications. Phys. E 2020, 121, 113830. [CrossRef]

48. Kumar, P.V.; Kala, S.M.J.; Prakash, K.S. Green synthesis of gold nanoparticles using Croton Caudatus Geisel leaf extract and their biological studies. Mater. Lett. 2019, 236, 19-22. [CrossRef]

49. Anand, K.; Gengan, R.M.; Phulukdaree, A.; Chuturgoon, A. Agroforestry waste Moringa oleifera petals mediated green synthesis of gold nanoparticles and their anti-cancer and catalytic activity. J. Ind. Eng. Chem. 2015, 21, 1105-1111. [CrossRef]

50. Sathishkumar, M.; Pavagadhi, S.; Mahadevan, A.; Balasubramanian, R. Biosynthesis of gold nanoparticles and related cytotoxicity evaluation using A549 cells. Ecotox. Environ. Saf. 2015, 114, 232-240. [CrossRef]

51. Gopinath, K.; Venkatesh, K.S.; Ilangovan, R.; Sankaranarayanan, K.; Arumugam, A. Green synthesis of gold nanoparticles from leaf extract of Terminalia arjuna, for the enhanced mitotic cell division and pollen germination activity. Ind. Crops Prod. 2013, 50, 737-742. [CrossRef]

52. Kumar, K.P.; Paul, W.; Sharma, C.P. Green synthesis of gold nanoparticles with Zingiber officinale extract: Characterization and blood compatibility. Process Biochem. 2011, 46, 2007-2013. [CrossRef]

53. Noruzi, M.; Zare, D.; Khoshnevisan, K.; Davoodi, D. Rapid green synthesis of gold nanoparticles using Rosa hybrida petal extract at room temperature. Spectrochim. Acta A Mol. Biomol. Spectrosc. 2011, 79, 1461-1465. [CrossRef] [PubMed]

54. Kumar, K.M.; Mandal, B.K.; Sinha, M.; Krishnakumar, V. Terminalia chebula mediated green and rapid synthesis of gold nanoparticles. Spectrochim. Acta A Mol. Biomol. Spectrosc. 2012, 86, 490-494. [CrossRef] [PubMed]

55. Guo, M.; Li, W.; Yang, F.; Liu, H. Controllable biosynthesis of gold nanoparticles from a Eucommia ulmoides bark aqueous extract. Spectrochim. Acta A Mol. Biomol. Spectrosc. 2015, 142, 73-79. [CrossRef]

56. Ganesan, R.M.; Prabu, H.G. Synthesis of gold nanoparticles using herbal Acorus calamus rhizome extract and coating on cotton fabric for antibacterial and UV blocking applications. Arab. J. Chem. 2019, 12, 2166-2174. [CrossRef]

57. Muniyappan, N.; Nagarajan, N.S. Green synthesis of gold nanoparticles using Curcuma pseudomontana essential oil, its biological activity and cytotoxicity against human ductal breast carcinoma cells T47D. J. Environ. Chem. Eng. 2014, 2, 2037-2044. [CrossRef]

58. Sujitha, M.V.; Kannan, S. Green synthesis of gold nanoparticles using Citrus fruits (Citrus limon, Citrus reticulata and Citrus sinensis) aqueous extract and its characterization. Spectrochim. Acta A Mol. Biomol. Spectrosc. 2013, 102, 15-23. [CrossRef]

59. Nasrollahzadeh, M.; Sajadi, S.M.; Maham, M. Green synthesis of palladium nanoparticles using Hippophae rhamnoides Linn leaf extract and their catalytic activity for the Suzuki-Miyaura coupling in water. J. Mol. Catal. A Chem. 2015, 396, 297-303. [CrossRef]

60. Khazaei, A.; Rahmati, S.; Hekmatian, Z.; Saeednia, S. A green approach for the synthesis of palladium nanoparticles supported on pectin: Application as a catalyst for solvent-free Mizoroki-Heck reaction. J. Mol. Catal. A Chem. 2013, 372, 160-166. [CrossRef]

61. Bankar, A.; Joshi, B.; Kumar, A.R.; Zinjarde, S. Banana peel extract mediated novel route for the synthesis of palladium nanoparticles. Mater. Lett. 2010, 64, 1951-1953. [CrossRef]

62. Yang, X.; Li, Q.; Wang, H.; Huang, J.; Lin, L.; Wang, W.; Sun, D.; Su, Y.; Opiyo, J.B.; Hong, L.; et al. Green synthesis of palladium nanoparticles using broth of Cinnamomum camphora leaf. J. Nanoparticle Res. 2010, 12, 1589-1598. [CrossRef]

63. Kalaiselvi, A.; Roopan, S.M.; Madhumitha, G.; Ramalingam, C.; Elango, G. Synthesis and characterization of palladium nanoparticles using Catharanthus roseus leaf extract and its application in the photo-catalytic degradation. Spectrochim. Acta A Mol. Biomol. Spectrosc. 2015, 135, 116-119. [CrossRef] [PubMed]

64. Kumar, K.M.; Mandal, B.K.; Kumar, K.S.; Reddy, P.S.; Sreedhar, B. Biobased green method to synthesise palladium and iron nanoparticles using Terminalia chebula aqueous extract. Spectrochim. Acta A Mol. Biomol. Spectrosc. 2013, 102, 128-133. [CrossRef] [PubMed]

65. Rabiee, N.; Bagherzadeh, M.; Kiani, M.; Ghadiri, A.M. Rosmarinus officinalis directed palladium nanoparticle synthesis: Investigation of potential anti-bacterial, anti-fungal and Mizoroki-Heck catalytic activities. Adv. Powder Technol. 2020, 31, 1402-1411. [CrossRef]

66. Kora, A.J.; Rastogi, L. Green synthesis of palladium nanoparticles using gum ghatti (Anogeissus latifolia) and its application as an antioxidant and catalyst. Arab. J. Chem. 2018, 11, 1097-1106. [CrossRef]

67. Joseph Kirubaharan, C.; Fang, Z.; Sha, C.; Yong, Y.C. Green synthesis of Ag and Pd nanoparticles for water pollutants treatment. Water Sci. Technol. 2020, 82, 2344-2352. [CrossRef]

68. Lebaschi, S.; Hekmati, M.; Veisi, H. Green synthesis of palladium nanoparticles mediated by black tea leaves (Camellia sinensis) extract: Catalytic activity in the reduction of 4-nitrophenol and Suzuki-Miyaura coupling reaction under ligand-free conditions. J. Colloid Interface Sci. 2017, 485, 223-231. [CrossRef]

69. Sheny, D.S.; Philip, D.; Mathew, J. Synthesis of platinum nanoparticles using dried Anacardium occidentale leaf and its catalytic and thermal applications. Spectrochim. Acta A Mol. Biomol. Spectrosc. 2013, 114, 267-271. [CrossRef] [PubMed]

70. Zheng, B.; Kong, T.; Jing, X.; Odoom-Wubah, T.; Li, X.; Sun, D.; Lu, F.; Zheng, Y.; Huang, J.; Li, Q. Plant-mediated synthesis of platinum nanoparticles and its bioreductive mechanism. J. Colloid Interface Sci. 2013, 396, 138-145. [CrossRef]

71. Raut, R.W.; Haroon, A.S.M.; Malghe, Y.S.; Nikam, B.T.; Kashid, S.B. Rapid biosynthesis of platinum and palladium metal nanoparticles using root extract of Asparagus racemosus Linn. Adv. Mater. Lett. 2013, 4, 650-654. [CrossRef] 
72. Song, J.Y.; Kwon, E.Y.; Kim, B.S. Biological synthesis of platinum nanoparticles using Diopyros kaki leaf extract. Bioproc. Biosyst. Eng. 2010, 33, 159-164. [CrossRef] [PubMed]

73. Soundarrajan, C.; Sankari, A.; Dhandapani, P.; Maruthamuthu, S.; Ravichandran, S.; Sozhan, G.; Palaniswamy, N. Rapid biological synthesis of platinum nanoparticles using Ocimum sanctum for water electrolysis applications. Bioproc. Biosyst. Eng. 2012, 35, 827-833. [CrossRef]

74. Razavi, R.; Molaei, R.; Moradi, M.; Tajik, H.; Ezati, P.; Yordshahi, A.S. Biosynthesis of metallic nanoparticles using mulberry fruit (Morus alba L.) extract for the preparation of antimicrobial nanocellulose film. Appl. Nanosci. 2020, 10, 465-476. [CrossRef]

75. Lotha, R.; Shamprasad, B.R.; Sundaramoorthy, N.S.; Nagarajan, S.; Sivasubramanian, A. Biogenic phytochemicals (cassinopin and isoquercetin) capped copper nanoparticles (ISQ/CAS@ CuNPs) inhibits MRSA biofilms. Microb. Pathog. 2019, 132, 178-187. [CrossRef] [PubMed]

76. Khani, R.; Roostaei, B.; Bagherzade, G.; Moudi, M. Green synthesis of copper nanoparticles by fruit extract of Ziziphus spina-christi (L.) Willd: Application for adsorption of triphenylmethane dye and antibacterial assay. J. Mol. Liq. 2018, 255, 541-549. [CrossRef]

77. Rajesh, K.M.; Ajitha, B.; Reddy, Y.A.K.; Suneetha, Y.; Reddy, P.S. Assisted green synthesis of copper nanoparticles using Syzygium aromaticum bud extract: Physical, optical and antimicrobial properties. Optik 2018, 154, 593-600. [CrossRef]

78. Lin, Z.; Weng, X.; Owens, G.; Chen, Z. Simultaneous removal of $\mathrm{Pb}$ (II) and rifampicin from wastewater by iron nanoparticles synthesized by a tea extract. J. Clean. Prod. 2020, 242, 118476. [CrossRef]

79. Katata-Seru, L.; Moremedi, T.; Aremu, O.S.; Bahadur, I. Green synthesis of iron nanoparticles using Moringa oleifera extracts and their applications: Removal of nitrate from water and antibacterial activity against Escherichia coli. J. Mol. Liq. 2018, 256, 296-304. [CrossRef]

80. Radini, I.A.; Hasan, N.; Malik, M.A.; Khan, Z. Biosynthesis of iron nanoparticles using Trigonella foenum-graecum seed extract for photocatalytic methyl orange dye degradation and antibacterial applications. J. Photochem. Photobiol. B 2018, 183, 154-163. [CrossRef]

81. Liang, T.; Qiu, X.; Ye, X.; Liu, Y.; Li, Z.; Tian, B.; Yan, D. Biosynthesis of selenium nanoparticles and their effect on changes in urinary nanocrystallites in calcium oxalate stone formation. 3 Biotech 2020, 10, 1-6. [CrossRef]

82. Yazhiniprabha, M.; Vaseeharan, B. In vitro and in vivo toxicity assessment of selenium nanoparticles with significant larvicidal and bacteriostatic properties. Mat. Sci. Eng. C 2019, 103, 109763. [CrossRef]

83. Menon, S.; KS, S.D.; Agarwal, H.; Shanmugam, V.K. Efficacy of biogenic selenium nanoparticles from an extract of ginger towards evaluation on anti-microbial and anti-oxidant activities. Colloid Interf. Sci. Commun. 2019, 29, 1-8. [CrossRef]

84. Din, M.I.; Nabi, A.G.; Rani, A.; Aihetasham, A.; Mukhtar, M. Single step green synthesis of stable nickel and nickel oxide nanoparticles from Calotropis gigantea: Catalytic and antimicrobial potentials. Environ. Nanotechnol. Monit. Manag. 2018, 9, 29-36. [CrossRef]

85. Sudhasree, S.; Shakila Banu, A.; Brindha, P.; Kurian, G.A. Synthesis of nickel nanoparticles by chemical and green route and their comparison in respect to biological effect and toxicity. Toxicol. Environ. Chem. 2014, 96, 743-754. [CrossRef]

86. Makarov, V.V.; Love, A.J.; Sinitsyna, O.V.; Makarova, S.S.; Yaminsky, I.V.; Taliansky, M.E.; Kalinina, N.O. “Green” nanotechnologies: Synthesis of metal nanoparticles using plants. Acta Nat. 2014, 6, 35-44. [CrossRef]

87. Si, S.; Mandal, T.K. Tryptophan-based peptides to synthesize gold and silver nanoparticles: A mechanistic and kinetic study. Chem. Eur. J. 2007, 13, 3160-3168. [CrossRef]

88. Anjana, P.M.; Bindhu, M.R.; Umadevi, M.; Rakhi, R.B. Antibacterial and electrochemical activities of silver, gold, and palladium nanoparticles dispersed amorphous carbon composites. Appl. Surf. Sci. 2019, 479, 96-104. [CrossRef]

89. Dhanavel, S.; Manivannan, N.; Mathivanan, N.; Gupta, V.K.; Narayanan, V.; Stephen, A. Preparation and characterization of cross-linked chitosan/palladium nanocomposites for catalytic and antibacterial activity. J. Mol. Liq. 2018, 257, 32-41. [CrossRef]

90. Fang, G.; Li, W.; Shen, X.; Perez-Aguilar, J.M.; Chong, Y.; Gao, X.; Chai, Z.; Chen, C.; Ge, C.; Zhou, R. Differential Pd-nanocrystal facets demonstrate distinct antibacterial activity against Gram-positive and Gram-negative bacteria. Nat. Commun. 2018, 9, 1-9. [CrossRef]

91. Klaus-Joerger, T.; Joerger, R.; Olsson, E.; Granqvist, C.G. Bacteria as workers in the living factory: Metal-accumulating bacteria and their potential for materials science. Trends Biotechnol. 2001, 19, 15-20. [CrossRef]

92. Mohamed, A.A.; Fouda, A.; Abdel-Rahman, M.A.; Hassan, S.E.D.; El-Gamal, M.S.; Salem, S.S.; Shaheen, T.I. Fungal strain impacts the shape, bioactivity and multifunctional properties of green synthesized zinc oxide nanoparticles. Biocatal. Agric. Biotechnol. 2019, 19, 101103. [CrossRef]

93. Alsamhary, K.I. Eco-friendly synthesis of silver nanoparticles by Bacillus subtilis and their antibacterial activity. Saudi J. Biol. Sci. 2020, 27, 2185-2191. [CrossRef] [PubMed]

94. Klaus, T.; Joerger, R.; Olsson, E.; Granqvist, C.G. Silver-based crystalline nanoparticles, microbially fabricated. Proc. Natl. Acad. Sci. USA 1999, 96, 13611-13614. [CrossRef] [PubMed]

95. Kalishwaralal, K.; Deepak, V.; Ramkumarpandian, S.; Nellaiah, H.; Sangiliyandi, G. Extracellular biosynthesis of silver nanoparticles by the culture supernatant of Bacillus licheniformis. Mater. Lett. 2008, 62, 4411-4413. [CrossRef]

96. Thomas, R.; Janardhanan, A.; Varghese, R.T.; Soniya, E.V.; Mathew, J.; Radhakrishnan, E.K. Antibacterial properties of silver nanoparticles synthesized by marine Ochrobactrum sp. Braz. J. Microbiol. 2014, 45, 1221-1227. [CrossRef] [PubMed] 
97. Monowar, T.; Rahman, M.; Bhore, S.J.; Raju, G.; Sathasivam, K.V. Silver nanoparticles synthesized by using the endophytic bacterium Pantoea ananatis are promising antimicrobial agents against multidrug resistant bacteria. Molecules 2018, 23, 3220. [CrossRef]

98. Wypij, M.; Golinska, P.; Dahm, H.; Rai, M. Actinobacterial-mediated synthesis of silver nanoparticles and their activity against pathogenic bacteria. IET Nanobiotechnol. 2016, 11, 336-342. [CrossRef]

99. Husseiny, M.I.; Abd El-Aziz, M.; Badr, Y.; Mahmoud, M.A. Biosynthesis of gold nanoparticles using Pseudomonas aeruginosa. Spectrochim. Acta A Mol. Biomol. Spectrosc. 2007, 67, 1003-1006. [CrossRef]

100. He, S.; Zhang, Y.; Guo, Z.; Gu, N. Biological synthesis of gold nanowires using extract of Rhodopseudomonas capsulata. Biotechnol. Progr. 2008, 24, 476-480. [CrossRef]

101. Du, L.; Jiang, H.; Liu, X.; Wang, E. Biosynthesis of gold nanoparticles assisted by Escherichia coli DH5 $\alpha$ and its application on direct electrochemistry of hemoglobin. Electrochem. Commun. 2007, 9, 1165-1170. [CrossRef]

102. Srinath, B.S.; Namratha, K.; Byrappa, K. Eco-friendly synthesis of gold nanoparticles by Bacillus subtilis and their environmental applications. Adv. Sci. Lett. 2018, 24, 5942-5946. [CrossRef]

103. Camas, M.; Camas, A.S.; Kyeremeh, K. Extracellular synthesis and characterization of gold nanoparticles using Mycobacterium sp. BRS2A-AR2 isolated from the aerial roots of the Ghanaian mangrove plant, Rhizophora racemosa. Indian J. Microbiol. 2018, 58, 214-221. [CrossRef]

104. Ahmed, E.; Kalathil, S.; Shi, L.; Alharbi, O.; Wang, P. Synthesis of ultra-small platinum, palladium and gold nanoparticles by Shewanella loihica PV-4 electrochemically active biofilms and their enhanced catalytic activities. J. Saudi Chem. Soc. 2018, 22, 919-929. [CrossRef]

105. Tuo, Y.; Liu, G.; Dong, B.; Yu, H.; Zhou, J.; Wang, J.; Jin, R. Microbial synthesis of bimetallic PdPt nanoparticles for catalytic reduction of 4-nitrophenol. Environ. Sci. Pollut. Res. 2017, 24, 5249-5258. [CrossRef] [PubMed]

106. Eramabadi, P.; Masoudi, M.; Makhdoumi, A.; Mashreghi, M. Microbial cell lysate supernatant (CLS) alteration impact on platinum nanoparticles fabrication, characterization, antioxidant and antibacterial activity. Mat. Sci. Eng. C 2020, 117, 111292. [CrossRef]

107. Wang, W.; Zhang, B.; He, Z. Bioelectrochemical deposition of palladium nanoparticles as catalysts by Shewanella oneidensis MR-1 towards enhanced hydrogen production in microbial electrolysis cells. Electrochim. Acta 2019, 318, 794-800. [CrossRef]

108. Che, L.; Dong, Y.; Wu, M.; Zhao, Y.; Liu, L.; Zhou, H. Characterization of selenite reduction by Lysinibacillus sp. ZYM-1 and photocatalytic performance of biogenic selenium nanospheres. ACS Sust. Chem. Eng. 2017, 5, 2535-2543. [CrossRef]

109. Wang, T.; Yang, L.; Zhang, B.; Liu, J. Extracellular biosynthesis and transformation of selenium nanoparticles and application in $\mathrm{H}_{2} \mathrm{O}_{2}$ biosensor. Colloids Surfaces B 2010, 80, 94-102. [CrossRef] [PubMed]

110. Alam, H.; Khatoon, N.; Khan, M.A.; Husain, S.A.; Saravanan, M.; Sardar, M. Synthesis of selenium nanoparticles using probiotic bacteria Lactobacillus acidophilus and their enhanced antimicrobial activity against resistant bacteria. J. Clust. Sci. 2020, 31, 1003-1011. [CrossRef]

111. AbdelRahim, K.; Mahmoud, S.Y.; Ali, A.M.; Almaary, K.S.; Mustafa, A.E.Z.M.; Husseiny, S.M. Extracellular biosynthesis of silver nanoparticles using Rhizopus stolonifer. Saudi J. Biol. Sci. 2017, 24, 208-216. [CrossRef] [PubMed]

112. Jalal, M.; Ansari, M.A.; Alzohairy, M.A.; Ali, S.G.; Khan, H.M.; Almatroudi, A.; Raees, K. Biosynthesis of silver nanoparticles from oropharyngeal Candida glabrata isolates and their antimicrobial activity against clinical strains of bacteria and fungi. Nanomaterials 2018, 8, 586. [CrossRef] [PubMed]

113. Kobashigawa, J.M.; Robles, C.A.; Ricci, M.L.M.; Carmarán, C.C. Influence of strong bases on the synthesis of silver nanoparticles (AgNPs) using the ligninolytic fungi Trametes trogii. Saudi J. Biol. Sci. 2019, 26, 1331-1337. [CrossRef] [PubMed]

114. Elamawi, R.M.; Al-Harbi, R.E.; Hendi, A.A. Biosynthesis and characterization of silver nanoparticles using Trichoderma longibrachiatum and their effect on phytopathogenic fungi. Egypt. J. Biol. Pest Control 2018, 28, 1-11. [CrossRef]

115. Ahmed, A.A.; Hamzah, H.; Maaroof, M. Analyzing formation of silver nanoparticles from the filamentous fungus Fusarium oxysporum and their antimicrobial activity. Turk. J. Biol. 2018, 42, 54-62. [CrossRef]

116. Lotfy, W.A.; Alkersh, B.M.; Sabry, S.A.; Ghozlan, H.A. Biosynthesis of silver nanoparticles by Aspergillus terreus: Characterization, optimization, and biological activities. Front. Bioeng. Biotechnol. 2021, 9, 633468. [CrossRef]

117. Mohanta, Y.K.; Nayak, D.; Biswas, K.; Singdevsachan, S.K.; Abd_Allah, E.F.; Hashem, A.; Alqarawi, A.A.; Yadav, D.; Mohanta, T.K. Silver nanoparticles synthesized using wild mushroom show potential antimicrobial activities against food borne pathogens. Molecules 2018, 23, 655. [CrossRef]

118. Bonilla, J.J.A.; Guerrero, D.J.P.; Sáez, R.G.T.; Ishida, K.; Fonseca, B.B.; Rozental, S.; López, C.C.O. Green synthesis of silver nanoparticles using maltose and cysteine and their effect on cell wall envelope shapes and microbial growth of Candida spp. J. Nanosci. Nanotechnol. 2017, 17, 1729-1739. [CrossRef]

119. Joshi, C.G.; Danagoudar, A.; Poyya, J.; Kudva, A.K.; Dhananjaya, B.L. Biogenic synthesis of gold nanoparticles by marine endophytic fungus-Cladosporium cladosporioides isolated from seaweed and evaluation of their antioxidant and antimicrobial properties. Process Biochem. 2017, 63, 137-144.

120. Tripathi, R.M.; Shrivastav, B.R.; Shrivastav, A. Antibacterial and catalytic activity of biogenic gold nanoparticles synthesised by Trichoderma harzianum. IET Nanobiotechnol. 2018, 12, 509-513. [CrossRef]

121. El Domany, E.B.; Essam, T.M.; Ahmed, A.E.; Farghali, A.A. Biosynthesis physico-chemical optimization of gold nanoparticles as anti-cancer and synergetic antimicrobial activity using Pleurotus ostreatus fungus. J. Appl. Pharm. Sci. 2018, 8, 119-128. 
122. Shen, W.; Qu, Y.; Pei, X.; Li, S.; You, S.; Wang, J.; Zhang, Z.; Zhou, J. Catalytic reduction of 4-nitrophenol using gold nanoparticles biosynthesized by cell-free extracts of Aspergillus sp. WL-Au. J. Hazard. Mater. 2017, 321, 299-306. [CrossRef]

123. Kitching, M.; Choudhary, P.; Inguva, S.; Guo, Y.; Ramani, M.; Das, S.K.; Marsili, E. Fungal surface protein mediated one-pot synthesis of stable and hemocompatible gold nanoparticles. Enzym. Microb. Technol. 2016, 95, 76-84. [CrossRef]

124. Subramaniyan, S.A.; Sheet, S.; Vinothkannan, M.; Yoo, D.J.; Lee, Y.S.; Belal, S.A.; Shim, K.S. One-pot facile synthesis of Pt nanoparticles using cultural filtrate of microgravity simulated grown P. chrysogenum and their activity on bacteria and cancer cells. J. Nanosci. Nanotechnol. 2018, 18, 3110-3125. [CrossRef] [PubMed]

125. Riddin, T.L.; Gericke, M.; Whiteley, C.G. Analysis of the inter-and extracellular formation of platinum nanoparticles by Fusarium oxysporum f. sp. lycopersici using response surface methodology. Nanotechnology 2006, 17, 3482.

126. Bansal, V.; Rautaray, D.; Bharde, A.; Ahire, K.; Sanyal, A.; Ahmad, A.; Sastry, M. Fungus-mediated biosynthesis of silica and titania particles. J. Mater. Chem. 2005, 15, 2583-2589. [CrossRef]

127. Soliman, H.; Elsayed, A.; Dyaa, A. Antimicrobial activity of silver nanoparticles biosynthesised by Rhodotorula sp. strain ATL72. Egypt. J. Basic Appl. Sci. 2018, 5, 228-233. [CrossRef]

128. Korbekandi, H.; Mohseni, S.; Mardani Jouneghani, R.; Pourhossein, M.; Iravani, S. Biosynthesis of silver nanoparticles using Saccharomyces cerevisiae. Artif. Cell Nanomed. Biotechnol. 2016, 44, 235-239. [CrossRef]

129. Fernández, J.G.; Fernández-Baldo, M.A.; Berni, E.; Camí, G.; Durán, N.; Raba, J.; Sanz, M.I. Production of silver nanoparticles using yeasts and evaluation of their antifungal activity against phytopathogenic fungi. Process Biochem. 2016, 51, 1306-1313. [CrossRef]

130. Cunha, F.A.; da CSO Cunha, M.; da Frota, S.M.; Mallmann, E.J.; Freire, T.M.; Costa, L.S.; Paula, A.J.; Menezes, E.A.; Fechine, P.B. Biogenic synthesis of multifunctional silver nanoparticles from Rhodotorula glutinis and Rhodotorula mucilaginosa: Antifungal, catalytic and cytotoxicity activities. World J. Microbiol. Biotechnol. 2018, 34, 1-15. [CrossRef]

131. Yang, Z.; Li, Z.; Lu, X.; He, F.; Zhu, X.; Ma, Y.; He, R.; Gao, F.; Ni, W.; Yi, Y. Controllable biosynthesis and properties of gold nanoplates using yeast extract. Nano Micro Lett. 2017, 9, 1-13. [CrossRef]

132. Qu, Y.; You, S.; Zhang, X.; Pei, X.; Shen, W.; Li, Z.; Li, S.; Zhang, Z. Biosynthesis of gold nanoparticles using cell-free extracts of Magnusiomyces ingens LH-F1 for nitrophenols reduction. Bioprocess Biosyst. Eng. 2018, 41, 359-367. [CrossRef]

133. Sriramulu, M.; Sumathi, S. Biosynthesis of palladium nanoparticles using Saccharomyces cerevisiae extract and its photocatalytic degradation behaviour. Adv. Nat. Sci. Nanosci. Nanotechnol. 2018, 9, 025018. [CrossRef]

134. Lian, S.; Diko, C.S.; Yan, Y.; Li, Z.; Zhang, H.; Ma, Q.; Qu, Y. Characterization of biogenic selenium nanoparticles derived from cell-free extracts of a novel yeast Magnusiomyces ingens. 3 Biotech 2019, 9, 1-8. [CrossRef]

135. Wadhwani, S.A.; Shedbalkar, U.U.; Singh, R.; Vashisth, P.; Pruthi, V.; Chopade, B.A. Kinetics of synthesis of gold nanoparticles by Acinetobacter sp. SW30 isolated from Environment. Indian J. Microbiol. 2016, 56, 439-444. [CrossRef]

136. Tan, K.B.; Sun, D.; Huang, J.; Odoom-Wubah, T.; Li, Q. State of arts on the bio-synthesis of noble metal nanoparticles and their biological application. Chin. J. Chem. Eng. 2020, 30, 272-290. [CrossRef]

137. Prabhu, S.; Poulose, E.K. Silver nanoparticles: Mechanism of antimicrobial action, synthesis, medical applications, and toxicity effects. Int. Nano Lett. 2012, 2, 32. [CrossRef]

138. Sabri, M.A.; Umer, A.; Awan, G.H.; Hassan, M.F.; Hasnain, A. Selection of suitable biological method for the synthesis of silver nanoparticles. Nanomater. Nanotechnol. 2016, 6, 29. [CrossRef]

139. Gurunathan, S.; Han, J.; Park, J.H.; Kim, J.H. A green chemistry approach for synthesizing biocompatible gold nanoparticles. Nanoscale Res. Lett. 2014, 9, 1-11. [CrossRef]

140. Dubey, S.P.; Lahtinen, M.; Sillanpää, M. Tansy fruit mediated greener synthesis of silver and gold nanoparticles. Process Biochem. 2010, 45, 1065-1071. [CrossRef]

141. Sathishkumar, M.; Sneha, K.; Yun, Y.S. Immobilization of silver nanoparticles synthesized using Curcuma longa tuber powder and extract on cotton cloth for bactericidal activity. Bioresour. Technol. 2010, 101, 7958-7965. [CrossRef]

142. Armendariz, V.; Herrera, I.; Jose-yacaman, M.; Troiani, H.; Santiago, P.; Gardea-Torresdey, J.L. Size controlled gold nanoparticle formation by Avena sativa biomass: Use of plants in nanobiotechnology. J. Nanoparticle Res. 2004, 6, 377-382. [CrossRef]

143. Chandran, S.P.; Chaudhary, M.; Pasricha, R.; Ahmad, A.; Sastry, M. Synthesis of gold nanotriangles and silver nanoparticles using Aloevera plant extract. Biotechnol. Progr. 2006, 22, 577-583. [CrossRef]

144. Kaviya, S.; Santhanalakshmi, J.; Viswanathan, B.; Muthumary, J.; Srinivasan, K. Biosynthesis of silver nanoparticles using Citrus sinensis peel extract and its antibacterial activity. Spectrochim. Acta A Mol. Biomol. Spectrosc. 2011, 79, 594-598. [CrossRef]

145. Mourdikoudis, S.; Pallares, R.M.; Thanh, N.T. Characterization techniques for nanoparticles: Comparison and complementarity upon studying nanoparticle properties. Nanoscale 2018, 10, 12871-12934. [CrossRef]

146. Punia, P.; Bharti, M.K.; Chalia, S.; Dhar, R.; Ravelo, B.; Thakur, P.; Thakur, A. Recent advances in synthesis, characterization, and applications of nanoparticles for contaminated water treatment-A review. Ceram. Int. 2021, 47, 1526-1550. [CrossRef]

147. Usman, M.; Farooq, M.; Wakeel, A.; Nawaz, A.; Cheema, S.A.; ur Rehman, H.; Ashraf, I.; Sanaullah, M. Nanotechnology in agriculture: Current status, challenges and future opportunities. Sci. Total Environ. 2020, 721, 137778. [CrossRef] [PubMed]

148. Nadiminti, P.P.; Dong, Y.D.; Sayer, C.; Hay, P.; Rookes, J.E.; Boyd, B.J.; Cahill, D.M. Nanostructured liquid crystalline particles as an alternative delivery vehicle for plant agrochemicals. ACS Appl. Mater. Interfaces 2013, 5, 1818-1826. [CrossRef]

149. Aslani, F.; Bagheri, S.; Muhd Julkapli, N.; Juraimi, A.S.; Hashemi, F.S.G.; Baghdadi, A. Effects of engineered nanomaterials on plants growth: An overview. Sci. World J. 2014, 2014, 641759. [CrossRef] [PubMed] 
150. Khodakovskaya, M.; Dervishi, E.; Mahmood, M.; Xu, Y.; Li, Z.; Watanabe, F.; Biris, A.S. Carbon nanotubes are able to penetrate plant seed coat and dramatically affect seed germination and plant growth. ACS Nano 2009, 3, 3221-3227. [CrossRef] [PubMed]

151. Kasote, D.M.; Lee, J.; Jayaprakasha, G.K.; Patil, B.S. Seed priming with iron oxide nanoparticles modulate antioxidant potential and defense linked hormones in watermelon seedlings. ACS Sust. Chem. Eng. 2019, 7, 5142. [CrossRef]

152. Lu, C.; Zhang, C.; Wen, J.; Wu, G.; Tao, M. Research of the effect of nanometer materials on germination and growth enhancement of Glycine max and its mechanism. Soybean Sci. 2002, 21, 168-171.

153. Zheng, L.; Hong, F.; Lu, S.; Liu, C. Effect of nano-TiO 2 on strength of naturally aged seeds and growth of spinach. Biol. Trace Elem. Res. 2005, 104, 83-91. [CrossRef]

154. Yang, F.; Hong, F.; You, W.; Liu, C.; Gao, F.; Wu, C.; Yang, P. Influence of nano-anatase $\mathrm{TiO}_{2}$ on the nitrogen metabolism of growing spinach. Biol. Trace Elem. Res. 2006, 110, 179-190. [CrossRef]

155. Li, J.; Chang, P.R.; Huang, J.; Wang, Y.; Yuan, H.; Ren, H. Physiological effects of magnetic iron oxide nanoparticles towards watermelon. J. Nanosci. Nanotechnol. 2013, 13, 5561-5567. [CrossRef]

156. Siddiqui, M.H.; Al-Whaibi, M.H. Role of nano-SiO 2 in germination of tomato (Lycopersicum esculentum) seeds Mill. Saudi J. Biol. Sci. 2014, 21, 13-17. [CrossRef] [PubMed]

157. Raliya, R.; Tarafdar, J.C. ZnO nanoparticle biosynthesis and its effect on phosphorous-mobilizing enzyme secretion and gum contents in Clusterbean (Cyamopsis tetragonoloba L.). Agric. Res. 2013, 2, 48-57. [CrossRef]

158. Mazaheri-Tirani, M.; Dayani, S. In vitro effect of zinc oxide nanoparticles on Nicotiana tabacum callus compared to $\mathrm{ZnO}$ micro particles and zinc sulfate $\left(\mathrm{ZnSO}_{4}\right)$. Plant Cell Tissue Organ Cult. 2020, 140, 279-289. [CrossRef]

159. Noori, A.; Donnelly, T.; Colbert, J.; Cai, W.; Newman, L.A.; White, J.C. Exposure of tomato (Lycopersicon esculentum) to silver nanoparticles and silver nitrate: Physiological and molecular response. Int. J. Phytoremediation 2020, 22, 40-51. [CrossRef] [PubMed]

160. Anjum, N.A.; Rodrigo, M.A.M.; Moulick, A.; Heger, Z.; Kopel, P.; Zitka, O.; Adam, V.; Lukatkin, A.S.; Duarte, A.C.; Pereira, E. Transport phenomena of nanoparticles in plants and animals/humans. Environ. Res. 2016, 151, 233-243. [CrossRef]

161. Irshad, M.A.; Nawaz, R.; ur Rehman, M.Z.; Adrees, M.; Rizwan, M.; Ali, S.; Ahmad, S.; Tasleem, S. Synthesis, characterization and advanced sustainable applications of titanium dioxide nanoparticles: A review. Ecotoxicol Environ. Saf. 2021, 212 , 111978. [CrossRef] [PubMed]

162. Acharya, P.; Jayaprakasha, G.K.; Crosby, K.M.; Jifon, J.L.; Patil, B.S. Green-synthesized nanoparticles enhanced seedling growth, yield, and quality of onion (Allium cepa L.). ACS Sust. Chem. Eng. 2019, 7, 14580-14590. [CrossRef]

163. Sehnal, K.; Hosnedlova, B.; Docekalova, M.; Stankova, M.; Uhlirova, D.; Tothova, Z.; Kepinska, M.; Milnerowicz, H.; Fernandez, C.; Ruttkay-Nedecky, B.; et al. An assessment of the effect of green synthesized silver nanoparticles using sage leaves (Salvia officinalis L.) on germinated plants of maize (Zea mays L.). Nanomaterials 2019, 9, 1550. [CrossRef]

164. Hasan, M.; Rafique, S.; Zafar, A.; Loomba, S.; Khan, R.; Hassan, S.G.; Khan, M.W.; Zahra, S.; Zia, M.; Mustafa, G.; et al. Physiological and anti-oxidative response of biologically and chemically synthesized iron oxide: Zea mays a case study. Heliyon 2020, 6, 1-7. [CrossRef]

165. Ramírez-Rodríguez, G.B.; Dal Sasso, G.; Carmona, F.J.; Miguel-Rojas, C.; Pérez-De-Luque, A.; Masciocchi, N.; Guagliardi, A.; Delgado-López, J.M. Engineering biomimetic calcium phosphate nanoparticles: A green synthesis of slow-release multinutrient (NPK) nanofertilizers. ACS Appl. Bio Mater. 2020, 3, 1344-1353. [CrossRef]

166. Rameshaiah, G.N.; Pallavi, J.; Shabnam, S. Nano fertilizers and nano sensors-An attempt for developing smart agriculture. Int. J. Eng. Res. Gen. Sci. 2015, 3, 314-320.

167. Mittal, D.; Kaur, G.; Singh, P.; Yadav, K.; Ali, S.A. Nanoparticle-Based Sustainable Agriculture and Food Science: Recent Advances and Future Outlook. Front. Nanotechnol. 2020, 2, 579954. [CrossRef]

168. Mastronardi, E.; Tsae, P.; Zhang, X.; Monreal, C.; DeRosa, M.C. Strategic role of nano-technology in fertilizers: Potential and limitations. In Nanotechnologies in Food and Agriculture; Springer: Berlin/Heidelberg, Germany, 2015; pp. 25-67.

169. Kottegoda, N.; Munaweera, I.; Madusanka, N.; Karunaratne, V. A green slow-release fertilizer composition based on ureamodified hydroxyapatite nanoparticles encapsulated wood. Curr. Sci. 2011, 101, 73-78.

170. Sethy, N.K.; Arif, Z.; Mishra, P.K.; Kumar, P. Green synthesis of $\mathrm{TiO}_{2}$ nanoparticles from Syzygium cumini extract for photo-catalytic removal of lead $(\mathrm{Pb})$ in explosive industrial wastewater. Green Process. Synth. 2020, 9, 171-181. [CrossRef]

171. Patidar, V.; Jain, P. Green synthesis of $\mathrm{TiO}_{2}$ nanoparticle using Moringa oleifera leaf extract. Int. Res. J. Eng. Technol. 2017, 4, 470-473.

172. Abisharani, J.M.; Devikala, S.; Kumar, R.D.; Arthanareeswari, M.; Kamaraj, P. Green synthesis of $\mathrm{TiO}_{2}$ nanoparticles using Cucurbita pepo seeds extract. Mater. Today Proc. 2019, 14, 302-307. [CrossRef]

173. Subhapriya, S.; Gomathipriya, P. Green synthesis of titanium dioxide $\left(\mathrm{TiO}_{2}\right)$ nanoparticles by Trigonella foenum-graecum extract and its antimicrobial properties. Microb. Pathog. 2018, 116, 215-220. [CrossRef]

174. Dimkpa, C.O.; Bindraban, P.S.; Fugice, J.; Agyin-Birikorang, S.; Singh, U.; Hellums, D. Composite micronutrient nanoparticles and salts decrease drought stress in soybean. Agro. Sustain. Dev. 2017, 37, 5. [CrossRef]

175. Delfani, M.; Baradarn Firouzabadi, M.; Farrokhi, N.; Makarian, H. Some physiological responses of black-eyed pea to iron and magnesium nanofertilizers. Commun. Soil Sci. Plant Anal. 2014, 45, 530-540. [CrossRef]

176. Liu, R.; Lal, R. Synthetic apatite nanoparticles as a phosphorus fertilizer for soybean (Glycine max). Sci. Rep. 2014, 4, 5686. [CrossRef] [PubMed] 
177. Jampílek, J.; Králová, K. Nanopesticides: Preparation, targeting, and controlled release. In New Pesticides and Soil Sensors; Grumezescu, A.M., Ed.; Academic Press: Cambridge, MA, USA, 2017; pp. 81-127.

178. Sasson, Y.; Levy-Ruso, G.; Toledano, O.; Ishaaya, I. Nanosuspensions: Emerging novel agrochemical formulations. In Insecticides Design Using Advanced Technologies; Springer: Berlin/Heidelberg, Germany, 2007; pp. 1-39.

179. Paret, M.L.; Vallad, G.E.; Averett, D.R.; Jones, J.B.; Olson, S.M. Photocatalysis: Effect of light-activated nanoscale formulations of $\mathrm{TiO}_{2}$ on Xanthomonas perforans and control of bacterial spot of tomato. Phytopathology 2013, 103, 228-236. [CrossRef]

180. Guan, Y.; Pearce, R.C.; Melechko, A.V.; Hensley, D.K.; Simpson, M.L.; Rack, P.D. Pulsed laser dewetting of nickel catalyst for carbon nanofiber growth. Nanotechnology 2008, 19, 235604. [CrossRef]

181. Zhao, L.; Lu, L.; Wang, A.; Zhang, H.; Huang, M.; Wu, H. Nano-biotechnology in agriculture: Use of nanomaterials to promote plant growth and stress tolerance. J. Agricul. Food. Chem. 2020, 68, 1935-1947. [CrossRef] [PubMed]

182. Ezhilarasi, P.N.; Karthik, P.; Chhanwal, N.; Anandharamakrishnan, C. Nanoencapsulation techniques for food bioactive components: A review. Food Bioprocess Tech. 2013, 6, 628-647. [CrossRef]

183. China Research and Intelligence. Global Nanotechnology for Food Packaging Market to Grow at 13.6\% CAGR, Which Is Anticipated to Reach USD 44.8 billion by 2030; China Research and Intelligence Co. Ltd.: Shanghai, China, 2021.

184. Assefa, Z.; Admassu, S. Development and characterization of antimicrobial packaging films. J. Food Process Technol. 2013, 4, 1-9. [CrossRef]

185. Kalita, D.; Baruah, S. The impact of nanotechnology on food. In Nanomaterials Applications for Environmental Matrices; Do Nascimento, R., Ferreira, O.P., De Paula, A.J., Neto, V.D.O.S., Eds.; Elsevier: Amsterdam, The Netherlands, 2019 ; pp. 369-379.

186. Krishna, R.; Campina, J.M.; Fernandes, P.M.V.; Ventura, J.; Titus, E.; Silva, A.F. Reduced graphene oxide-nickel nanoparticles/biopolymer composite films for sub-millimolar detection of glucose. Analyst 2016, 141, 4151-4161. [CrossRef]

187. Yang, L.; Chen, Y.; Shen, Y.; Yang, M.; Li, X.; Han, X.; Jiang, X.; Zhao, B. SERS strategy based on the modified Au nanoparticles for highly sensitive detection of bisphenol A residues in milk. Talanta 2018, 179, 37-42. [CrossRef]

188. Ahmed, S.; Ahmad, M.; Swami, B.; Ikram, S. A review on plants extract mediated synthesis of silver nanoparticles for antimicrobial applications: A green expertise. J. Adv. Res. 2016, 7, 17-28. [CrossRef]

189. Kanmani, P.; Rhim, J.W. Physical, mechanical and antimicrobial properties of gelatin based active nanocomposite films containing AgNPs and nanoclay. Food Hydrocoll. 2014, 35, 644-652. [CrossRef]

190. Shankar, S.; Teng, X.; Li, G.; Rhim, J.W. Preparation, characterization, and antimicrobial activity of gelatin/ZnO nanocomposite films. Food Hydrocoll. 2015, 45, 264-271. [CrossRef]

191. He, X.; Hwang, H.M. Nanotechnology in food science: Functionality, applicability, and safety assessment. J. Food Drug Anal. 2016, 24, 671-681. [CrossRef] [PubMed]

192. Aguilera, J.M. Nanotechnology in Food Products: Workshop Summary; Institute of Medicine (US) Food Forum; National Academies Press: Washington, DC, USA, 2009.

193. Singh, T.; Shukla, S.; Kumar, P.; Wahla, V.; Bajpai, V.K.; Rather, I.A. Application of nanotechnology in food science: Perception and overview. Front. Microbiol. 2017, 8, 1501. [CrossRef]

194. Graveland-Bikker, J.F.; De Kruif, C.G. Unique milk protein based nanotubes: Food and nanotechnology meet. Trends Food Sci. Technol. 2006, 17, 196-203. [CrossRef]

195. Oberdörster, G.; Stone, V.; Donaldson, K. Toxicology of nanoparticles: A historical perspective. Nanotoxicology 2007, 1, 2-25. [CrossRef]

196. Fernandez, A.; Cava, D.; Ocio, M.J.; Lagaron, M. Perspectives for biocatalysts in food packaging. Trends Food Sci. Technol. 2008, 19, 198-206. [CrossRef]

197. Pradhan, N.; Singh, S.; Ojha, N.; Shrivastava, A.; Barla, A.; Rai, V.; Bose, S. Facets of nanotechnology as seen in food processing, packaging, and preservation industry. BioMed Res. Int. 2015, 2015, 365672. [CrossRef]

198. Weir, A.; Westerhoff, P.; Fabricius, L.; Hristovski, K.; Goetz, N.V. Titanium dioxide nanoparticles in food and personal care products. Environ. Sci. Technol. 2012, 46, 2242-2250. [CrossRef]

199. Carbone, M.; Tommas, D.; Gianfranco, D.D.; Sabbatella, G.; Antiochia, R. Silver nanoparticles in polymeric matrices for fresh food packaging. J. King Saud Univ. Sci. 2016, 28, 273-279. [CrossRef]

200. Emamifar, A.; Kadivar, M.; Shahedi, M.; Soleimanian-Zad, S. Evaluation of nanocomposite packaging containing Ag and ZnO on shelf life of fresh orange juice. Innov. Food Sci. Emerg. Technol. 2010, 11, 742-748. [CrossRef]

201. Motlagh, N.V.; Mosavian, M.T.H.; Mortazavi, S.A. Effect of polyethylene packaging modified with silver particles on the microbial, sensory and appearance of dried barberry. Packag. Technol. Sci. 2012, 26, 39-49. [CrossRef]

202. Yang, F.M.; Li, H.M.; Li, F.; Xin, Z.H.; Zhao, L.Y.; Zheng, Y.H.; Hu, Q.H. Effect of nano-packing on preservation quality of fresh strawberry (Fragaria ananassa Duch. Cv Fengxiang) during storage at $4{ }^{\circ}$ C. J. Food Chem. 2010, 75, C236-C240. [CrossRef] [PubMed]

203. Martinez-Abad, A.; Lagaron, J.M.; Ocio, M.J. Development and characterization of silver-based antimicrobial ethylene-vinyl alcohol copolymer (EVOH) films for food-packaging applications. J. Agric. Food Chem. 2012, 60, 5350-5359. [CrossRef] [PubMed]

204. Mahdi, S.S.; Vadood, R.; Nourdahr, R. Study on the antimicrobial effect of nanosilver tray packaging of minced beef at refrigerator temperature. Glob. Vet. 2012, 9, 284-289.

205. Metak, A.M.; Ajaal, T.T. Investigation on polymer based nanosilver as food packaging materials. Int. J. Biol. Food Vet. Agric. Eng. 2013, 7, 772-777. 
206. Metak, A.M. Effects of nanocomposites based nano-silver and nano-titanium dioxideon food packaging materials. Int. J. Appl. Sci. Technol. 2015, 5, 26-40.

207. Akbari, Z.; Ghomashchi, T.; Aroujalian, A. Potential of nanotechnology for food packaging industry. In Proceedings of the "Nano Micro Technologies in the Food Health Food Industries" Conference organised by Institute of Nanotechnology, Amsterdam, The Netherland, 25-26 October 2006.

208. Khalaf, H.H.; Sharoba, A.M.; El-Tanahi, H.H.; Morsy, M.K. Stability of antimicrobial activity of pullulan edible films incorporated with nanoparticles and essential oils and their impact on turkey deli meat quality. J. Food Dairy Sci. 2013, 4, 557-573. [CrossRef]

209. Elsaesser, A.; Howard, C. Toxicology of nanoparticles. Adv. Drug Deliver. Rev. 2012, 64, 129-137. [CrossRef] [PubMed]

210. Zoroddu, M.; Medici, S.; Ledda, A.; Nurchi, V.M.; Lachowicz, J.I.; Peana, M. Toxicity of nanoparticles. Curr. Med. Chem. 2014, 21, 3837-3853. [CrossRef] [PubMed]

211. Sebastian, R. Nanomedicine-The future of cancer treatment: A Review. J. Cancer Prev. Curr. Res. 2017, 8, 00265. [CrossRef]

212. Venugopal, K.; Rather, H.A.; Rajagopal, K.; Shanthi, M.P.; Sheriff, K.; Illiyas, M.; Rather, R.A.; Manikandan, E.; Uvarajan, S.; Bhaskar, M.; et al. Synthesis of silver nanoparticles (Ag NPs) for anticancer activities (MCF 7 breast and A549 lung cell lines) of the crude extract of Syzygium aromaticum. J. Photochem. Photobiol. B 2017, 167, 282-289. [CrossRef]

213. Elangovan, K.; Elumalai, D.; Anupriya, S.; Shenbhagaraman, R.; Kaleena, P.; Murugesan, K. Phyto mediated biogenic synthesis of silver nanoparticles using leaf extract of Andrographis echioides and its bio-efficacy on anticancer and antibacterial activities. J. Photochem. Photobiol. B 2015, 151, 118-124. [CrossRef] [PubMed]

214. Arivazhagan, S.; Velmurugan, B.; Bhuvaneswari, V.; Nagini, S. Effects of aqueous extracts of garlic (Allium sativum) and neem (Azadirachta indica) leaf on hepatic and blood oxidant-antioxidant status during experimental gastric carcinogenesis. J. Med. Food 2004, 7, 334-339. [CrossRef]

215. Adewale, O.; Davids, H.; Cairncross, L.; Roux, S. Toxicological behavior of gold nanoparticles on various models: Influence of physicochemical properties and other factors. Int. J. Toxicol. 2019, 38, 357-384. [CrossRef]

216. Rao, P.; Nallappan, D.; Madhavi, K.; Rahman, S.; Jun Wei, L.; Gan, S. Phytochemicals and Biogenic Metallic Nanoparticles as Anticancer Agents. Oxid. Med. Cell. Longev. 2016, 1-15. [CrossRef]

217. Farshchi, H.; Azizi, M.; Jaafari, M.; Nemati, S.; Fotovat, A. Green synthesis of iron nanoparticles by Rosemary extract and cytotoxicity effect evaluation on cancer cell lines. Biocatal. Agric. Biotechnol. 2018, 16, 54-62. [CrossRef]

218. Kostyukova, D.; Chung, Y. Synthesis of iron oxide nanoparticles using isobutanol. J. Nanomater. 2016, 2016, 1-9. [CrossRef]

219. Peng, X.H.; Qian, X.; Mao, H.; Wang, A.Y.; Chen, Z.G.; Nie, S.; Shin, D.M. Targeted magnetic iron oxide nanoparticles for tumor imaging and therapy. Int. J. Nanomed. 2008, 3, 311-321.

220. Anjum, M.; Miandad, R.; Waqas, M.; Gehany, F.; Barakat, M.A. Remediation of wastewater using various nano-materials. Arab. J. Chem. 2019, 12, 4897-4919. [CrossRef]

221. Sharma, S.; Bhattacharya, A. Drinking water contamination and treatment techniques. Appl. Water Sci. 2017, 7, 1043-1067. [CrossRef]

222. Gautam, R.K.; Chattopadhyaya, M.C. Nanomaterials for Wastewater Remediation; Elsevier: Amsterdam, The Netherlands, 2016.

223. Sadegh, H.; Ali, G.A.; Gupta, V.K.; Makhlouf, A.S.H.; Shahryari-ghoshekandi, R.; Nadagouda, M.N.; Sillanpää, M.; Megiel, E. The role of nanomaterials as effective adsorbents and their applications in wastewater treatment. J. Nanostruct. Chem. 2017, 7, 1-14. [CrossRef]

224. Dil, E.A.; Ghaedi, M.; Asfaram, A. The performance of nanorods material as adsorbent for removal of azo dyes and heavy metal ions: Application of ultrasound wave, optimization and modeling. Ultrason. Sonochem. 2017, 34, 792-802. [CrossRef] [PubMed]

225. Santhosh, C.; Velmurugan, V.; Jacob, G.; Jeong, S.K.; Grace, A.N.; Bhatnagar, A. Role of nanomaterials in water treatment applications: A review. Chem. Eng. J. 2016, 306, 1116-1137. [CrossRef]

226. El-Sayed, M.E. Nanoadsorbents for water and wastewater remediation. Sci. Total Environ. 2020, 739, 139903. [CrossRef] [PubMed]

227. Zhao, C.; Wang, B.; Theng, B.K.; Wu, P.; Liu, F.; Wang, S.; Lee, X.; Chen, M.; Li, L.; Zhang, X. Formation and mechanisms of nano-metal oxide-biochar composites for pollutant removal: A review. Sci. Total Environ. 2021, 767, 145305. [CrossRef]

228. Das, C.; Sen, S.; Singh, T.; Ghosh, T.; Paul, S.S.; Kim, T.W.; Jeon, S.; Maiti, D.K.; Im, J.; Biswas, G. Green synthesis, characterization and application of natural product coated magnetite nanoparticles for wastewater treatment. Nanomaterials 2020, 10, 1615. [CrossRef]

229. Al-Qahtani, K.M. Cadmium removal from aqueous solution by green synthesis zero valent silver nanoparticles with Benjamina leaves extract. Egypt. J. Aquat. Res. 2017, 43, 269-274. [CrossRef]

230. Ehrampoush, M.H.; Miria, M.; Salmani, M.H.; Mahvi, A.H. Cadmium removal from aqueous solution by green synthesis iron oxide nanoparticles with tangerine peel extract. J. Environ. Health Sci. 2015, 13, 1-7. [CrossRef] [PubMed]

231. Primo, J.D.O.; Bittencourt, C.; Acosta, S.; Sierra-Castillo, A.; Colomer, J.F.; Jaerger, S.; Teixeira, V.C.; Anaissi, F.J. Synthesis of Zinc Oxide nanoparticles by ecofriendly routes: Adsorbent for copper removal from wastewater. Front. Chem. 2020, 8 , 571790. [CrossRef]

232. Zhu, Y.; Liu, X.; Hu, Y.; Wang, R.; Chen, M.; Wu, J.; Wang, Y.; Kang, S.; Sun, Y.; Zhu, M. Behavior, remediation effect and toxicity of nanomaterials in water environments. Environ. Res. 2019, 174, 54-60. [CrossRef]

233. Wang, P.; Wang, F.; Jiang, H.; Zhang, Y.; Zhao, M.; Xiong, R.; Ma, J. Strong improvement of nanofiltration performance on micropollutant removal and reduction of membrane fouling by hydrolyzed-aluminum nanoparticles. Water Res. 2020, 175, 115649. [CrossRef] 
234. Bottino, A.; Capannelli, G.; D'asti, V.; Piaggio, P. Preparation and properties of novel organic-inorganic porous membranes. Sep. Purif. Technol. 2001, 22, 269-275. [CrossRef]

235. Fujiwara, M.; Imura, T. Photo induced membrane separation for water purification and desalination using azobenzene modified anodized alumina membranes. ACS Nano 2015, 9, 5705-5712. [CrossRef]

236. Maximous, N.; Nakhla, G.; Wong, K.; Wan, W. Optimization of $\mathrm{Al}_{2} \mathrm{O}_{3} /$ PES membranes for wastewater filtration. Sep. Purif. Technol. 2010, 73, 294-301. [CrossRef]

237. Yurekli, Y. Removal of heavy metals in wastewater by using zeolite nano-particles impregnated polysulfone membranes. J. Hazard. Mater. 2016, 309, 53-64. [CrossRef]

238. Bet-Moushoul, E.; Mansourpanah, Y.; Farhadi, K.; Tabatabaei, $\mathrm{M}^{\mathrm{TiO}} 2$ nanocomposite based polymeric membranes: A review on performance improvement for various applications in chemical engineering processes. Chem. Eng. J. 2016, 283, 29-46. [CrossRef]

239. Mauter, M.S.; Wang, Y.; Okemgbo, K.C.; Osuji, C.O.; Giannelis, E.P.; Elimelech, M. Antifouling ultrafiltration membranes via post-fabrication grafting of biocidal nanomaterials. ACS Appl. Mater. Inter. 2011, 3, 2861-2868. [CrossRef]

240. Zodrow, K.; Brunet, L.; Mahendra, S.; Li, D.; Zhang, A.; Li, Q.; Alvarez, P.J. Polysulfone ultrafiltration membranes impregnated with silver nanoparticles show improved biofouling resistance and virus removal. Water Res. 2009, 43, 715-723. [CrossRef]

241. Patanjali, P.; Singh, R.; Kumar, A.; Chaudhary, P. Nanotechnology for water treatment: A green approach. In Green Synthesis, Characterization and Applications of Nanoparticles; Shukla, A.K., Iravani, S., Eds.; Elsevier: Amsterdam, The Netherlands, 2019; pp. 485-512.

242. Anjum, M.; Al-Makishah, N.H.; Barakat, M.A. Wastewater sludge stabilization using pre-treatment methods. Process Saf. Environ. 2016, 102, 615-632. [CrossRef]

243. Hemmati, S.; Mehrazin, L.; Ghorban, H.; Garakani, S.H.; Mobaraki, T.H.; Mohammadi, P.; Veisi, H. Green synthesis of Pd nanoparticles supported on reduced graphene oxide, using the extract of Rosa canina fruit, and their use as recyclable and heterogeneous nanocatalysts for the degradation of dye pollutants in water. RSC Adv. 2018, 8, 21020-21028. [CrossRef]

244. Kumar, B.; Smita, K.; Cumbal, L. Phytosynthesis of gold nanoparticles using Andean Aj1' (Capsicum baccatum L.). Cogent Chem. 2015, 1, 1120982. [CrossRef]

245. Kumar, B.; Smita, K.; Cumbal, L.; Debut, A. One pot synthesis and characterization of gold nanocatalyst using Sacha inchi (Plukenetia volubilis) oil: Green approach. J. Photochem. Photobiol. B 2016, 158, 55-60. [CrossRef]

246. Sumi, M.B.; Devadiga, A.; Shetty, K.V.; Saidutta, M.B. Solar photocatalytically active, engineered silver nanoparticle synthesis using aqueous extract of mesocarp of Cocos nucifera (Red Spicata Dwarf). J. Exp. Nanosci. 2017, 12, 14-32. [CrossRef]

247. Tahir, K.; Nazir, S.; Li, B.; Khan, A.U.; Khan, Z.U.H.; Ahmad, A.; Khan, F.U. An efficient photo catalytic activity of green synthesized silver nanoparticles using Salvadora persica stem extract. Sep. Purif. Technol. 2015, 150, 316-324. [CrossRef]

248. Nagajyothi, P.C.; Prabhakar Vattikuti, S.V.; Devarayapalli, K.C.; Yoo, K.; Shim, J.; Sreekanth, T.V.M. Green synthesis: Photocatalytic degradation of textile dyes using metal and metal oxide nanoparticles-latest trends and advancements. Crit. Rev. Environ. Sci. Technol. 2020, 50, 2617-2723. [CrossRef]

249. Huh, A.J.; Kwon, Y.J. Nanoantibiotics: A new paradigm for treating infectious diseases using nanomaterials in the antibiotics resistant era. J. Control. Release 2011, 156, 128-145. [CrossRef]

250. Seil, J.T.; Webster, T.J. Antimicrobial applications of nanotechnology: Methods and literature. Int. J. Nanomed. 2012, 7, $2767-2781$.

251. Pelgrift, R.Y.; Friedman, A.J. Nanotechnology as a therapeutic tool to combat microbial resistance. Adv. Drug Deliv. Rev. 2013, 65, 1803-1815. [CrossRef] [PubMed]

252. Allahverdiyev, A.M.; Abamor, E.S.; Bagirova, M.; Rafailovich, M. Antimicrobial effects of $\mathrm{TiO}_{2}$ and $\mathrm{Ag}_{2} \mathrm{O}$ nanoparticles against drug-resistant bacteria and leishmania parasites. Future Microbiol. 2011, 6, 933-940. [CrossRef] [PubMed]

253. Tenover, F.C.; Hughes, J.M. The challenges of emerging infectious diseases: Development and spread of multiply-resistant bacterial pathogens. JAMA 1996, 275, 300-304. [CrossRef] [PubMed]

254. Dizaj, S.M.; Lotfipour, F.; Barzegar-Jalali, M.; Zarrintan, M.H.; Adibkia, K. Antimicrobial activity of the metals and metal oxide nanoparticles. Mater. Sci. Eng. C 2014, 44, 278-284. [CrossRef]

255. Besinis, A.; De Peralta, T.; Handy, R.D. The antibacterial effects of silver, titanium dioxide and silica dioxide nanoparticles compared to the dental disinfectant chlorhexidine on Streptococcus mutans using a suite of bioassays. Nanotoxicology 2014, 8 , 1-16. [CrossRef]

256. Lok, C.-N.; Ho, C.-M.; Chen, R.; He, Q.-Y.; Yu, W.-Y.; Sun, H.; Tam, P.K.-H.; Chiu, J.-F.; Che, C.-M. Silver nanoparticles: Partial oxidation and antibacterial activities. J. Biol. Inorg. Chem. 2007, 12, 527-534. [CrossRef]

257. Jiang, W.; Mashayekhi, H.; Xing, B. Bacterial toxicity comparison between nano- and micro-scaled oxide particles. Environ. Pollut. 2009, 157, 1619-1625. [CrossRef] [PubMed]

258. Chen, S.F.; Li, J.P.; Qian, K.; Xu, W.P.; Lu, Y.; Huang, W.X.; Yu, S.H. Large scale photochemical synthesis of $\mathrm{M}_{0} \mathrm{TiO}_{2}$ nanocomposites $(\mathrm{M}=\mathrm{Ag}, \mathrm{Pd}, \mathrm{Au}, \mathrm{Pt})$ and their optical properties, $\mathrm{CO}$ oxidation performance, and antibacterial effect. Nano Res. 2010, 3 , 244-255. [CrossRef]

259. Rajendra, R.; Balakumar, C.; Ahammed, H.A.M.; Jayakumar, S.; Vaideki, K.; Rajesh, E. Use of zinc oxide nano particles for production of antimicrobial textiles. Int. J. Eng. Sci. Technol. 2010, 2, 202-208. [CrossRef]

260. Kuang, Y.; He, X.; Zhang, Z.; Li, Y.; Zhang, H.; Ma, Y.; Wu, Z.; Chai, Z. Comparison study on the antibacterial activity of nano- or bulk-cerium oxide. J. Nanosci. Nanotechnol. 2011, 11, 4103-4108. [CrossRef] 
261. Li, S.-T.; Qiao, X.-L.; Chen, J.-G.; Wu, C.-L.; Mei, B. The investigation of antibacterial characteristics of magnesium oxide and it's nano-composite materials. J. Funct. Mater. 2005, 11, 1651-1654.

262. Srivastava, M.; Singh, S.; Self, W.T. Exposure to silver nanoparticles inhibits selenoprotein synthesis and the activity of thioredoxin reductase. Environ. Health Perspect. 2012, 120, 56-61. [CrossRef] [PubMed]

263. Singh, S.; Patel, P.; Jaiswal, S.; Prabhune, A.A.; Ramana, C.V.; Prasad, B.L.V. A direct method for the preparation of glycolipidmetal nanoparticle conjugates: Sophorolipids as reducing and capping agents for the synthesis of water re-dispersible silver nanoparticles and their antibacterial activity. New J. Chem. 2009, 33, 646-652. [CrossRef]

264. Masoumbaigi, H.; Rezaee, A.; Hosseini, H.; Hashemi, S. Water disinfection by zinc oxide nanoparticle prepared with solution combustion method. Desalin. Water Treat. 2015, 56, 2376-2381. [CrossRef]

265. Makhluf, S.; Dror, R.; Nitzan, Y.; Abramovich, Y.; Jelinek, R.; Gedanken, A. Microwave assisted synthesis of nanocrystalline MgO and its use as a bacteriocide. Adv. Funct. Mater. 2005, 15, 1708-1715. [CrossRef]

266. Abbaszadegan, A.; Ghahramani, Y.; Gholami, A.; Hemmateenejad, B.; Dorostkar, S.; Nabavizadeh, M.; Sharghi, H. The effect of charge at the surface of silver nanoparticles on antimicrobial activity against gram-positive and gram-negative bacteria: A preliminary study. J. Nanomater. 2015, 16,1-8. [CrossRef]

267. Adibkia, K.; Alaei-Beirami, M.; Barzegar-Jalali, M.; Mohammadi, G.; Ardestani, M.S. Evaluation and optimization of factors affecting novel diclofenac sodium-eudragit RS100 nanoparticles. Afr. J. Pharm. Pharmacol. 2012, 6, 941-947.

268. Buzea, C.; Pacheco, I.I.; Robbie, K. Nanomaterials and nanoparticles: Sources and toxicity. Biointerphases 2007, 2, MR17-MR71. [CrossRef]

269. Adibkia, K.; Barzegar-Jalali, M.; Nokhodchi, A.; Siahi Shadbad, M.; Omidi, Y.; Javadzadeh, Y.; Mohammadi, G. A review on the methods of preparation of pharmaceutical nanoparticles. J. Pharm. Sci. 2010, 15, 303-314.

270. Hoseinzadeh, E.; Alikhani, M.-Y.; Samarghandi, M.-R.; Shirzad-Siboni, M. Antimicrobial potential of synthesized zinc oxide nanoparticles against gram positive and gram negative bacteria. Desalin. Water Treat. 2014, 52, 4969-4976. [CrossRef]

271. Mirhosseini, M.; Firouzabadi, F.B. Reduction of listeria monocytogenes and Bacillus cereus in milk by zinc oxide nanoparticles. Iran J. Pathol. 2015, 10, 97-104.

272. Wongyai, K.; Wintachai, P.; Maungchang, R.; Rattanakit, P. Exploration of the antimicrobial and catalytic properties of gold nanoparticles greenly synthesized by Cryptolepis buchanani Roem. and Schult extract. J. Nanomater. 2020, 2020, 1320274. [CrossRef]

273. Loo, Y.Y.; Rukayadi, Y.; Nor-Khaizura, M.A.R.; Kuan, C.H.; Chieng, B.W.; Nishibuchi, M.; Radu, S. In vitro antimicrobial activity of green synthesized silver nanoparticles against selected Gram-negative food borne pathogens, Front. Microbiol. 2018, 9, 1555.

274. Pal, S.; Tak, Y.K.; Song, J.M. Does the antibacterial activity of silver nanoparticles depend on the shape of the nanoparticle? A study of the gram-negative bacterium Escherichia coli. Appl. Environ. Microbiol. 2007, 73, 1712-1720. [CrossRef] [PubMed]

275. Bera, R.K.; Mandal, S.M.; Raj, C.R. Antimicrobial activity of fluorescent Ag nanoparticles. Lett. Appl. Microbiol. 2014, 58, 520-526. [CrossRef]

276. Song, Y.; Chen, L. Effect of net surface charge on physical properties of the cellulose nanoparticles and their efficacy for oral protein delivery. Carbohyd. Polym. 2015, 121, 10-17. [CrossRef] [PubMed]

277. Tsuji, J.S.; Maynard, A.D.; Howard, P.C.; James, J.T.; Lam, C.-W.; Warheit, D.B.; Santamaria, A.B. Research strategies for safety evaluation of nanomaterials, part IV: Risk assessment of nanoparticles. Toxicol. Sci. 2006, 89, 42-50. [CrossRef] [PubMed]

278. De Jong, W.H.; Borm, P.J. Drug delivery and nanoparticles: Applications and hazards. Int. J. Nanomed. 2008, 3, 133. [CrossRef]

279. Zinjarde, S.S. Bio-inspired nanomaterials and their applications as antimicrobial agents. Chron. Young Sci. 2012, 3, 1-74. [CrossRef]

280. Khan, I.; Saeed, K.; Khan, I. Nanoparticles: Properties, applications and toxicities. Arab. J. Chem. 2019, 12, 908-931. [CrossRef]

281. Pulit-Prociak, J.; Banach, M. Silver nanoparticles-A material of the future? Open Chem. 2016, 14, 76-91. [CrossRef]

282. Giorgetti, L. Effects of nanoparticles in plants: Phytotoxicity and genotoxicity assessment. Nanomater. Plants Algae Microorg. 2019, $2,65-87$.

283. Semmler-Behnke, M.; Lipka, J.; Wenk, A.; Hirn, S.; Schäffler, M.; Tian, F.; Schmid, G.; Oberdörster, G.; Kreyling, W.G. Size dependent translocation and fetal accumulation of gold nanoparticles from maternal blood in the rat. Part. Fibre Toxicol. 2014, 11, 1-12. [CrossRef]

284. Gao, G.; Ze, Y.; Li, B.; Zhao, X.; Zhang, T.; Sheng, L.; Hu, R.; Gui, S.; Sang, X.; Sun, Q.; et al. Ovarian dysfunction and geneexpressed characteristics of female mice caused by long-term exposure to titanium dioxide nanoparticles. J. Hazard. Mater. 2012, 243, 19-27. [CrossRef] [PubMed]

285. Dash, S.R.; Kundu, C.N. Promising opportunities and potential risk of nanoparticle on the society. IET Nanobiotechnol. 2020, 14, 253-260. [CrossRef]

286. Wang, W.N.; Tarafdar, J.C.; Biswas, P. Nanoparticle synthesis and delivery by an aerosol route for watermelon plant foliar uptake. J. Nanoparticle. Res. 2013, 15, 1417. [CrossRef]

287. Tripathi, A.; Liu, S.; Singh, P.K.; Kumar, N.; Pandey, A.C.; Tripathi, D.K.; Chauhan, D.K.; Sahi, S. Differential phytotoxic responses of silver nitrate $\left(\mathrm{AgNO}_{3}\right)$ and silver nanoparticle (AgNps) in Cucumis sativus L. Plant Gene 2017, 11, 255-264. [CrossRef]

288. Zhu, Y.; Wu, J.; Chen, M.; Liu, X.; Xiong, Y.; Wang, Y.; Feng, T.; Kang, S.; Wang, X. Recent advances in the biotoxicity of metal oxide nanoparticles: Impacts on plants, animals and microorganisms. Chemosphere 2019, 237, 124403. [CrossRef]

289. Verma, S.K.; Das, A.K.; Patel, M.K.; Shah, A.; Kumar, V.; Gantait, S. Engineered nanomaterials for plant growth and development: A perspective analysis. Sci. Total Environ. 2018, 630, 1413-1435. [CrossRef] [PubMed] 
290. Barbafieri, M.; Giorgetti, L. Contaminant bioavailability in soil and phytotoxicity/genotoxicity tests in Vicia faba L.: A case study of boron contamination. Environ. Sci. Pollut. Res. Int. 2016, 23, 24327-24336. [CrossRef]

291. Adhikari, T.; Kundu, S.; Subba Rao, A. Impact of $\mathrm{SiO}_{2}$ and Mo nanoparticles on seed germination of rice (Oryza sativa L.). Int. J. Agric. Food Sci. Technol. 2013, 4, 809-816.

292. Qados, A.M.S.A. Mechanism of nanosilicon-mediated alleviation of salinity stress in faba bean (Vicia faba L.). Plants Am. J. Exp. Agric. 2015, 7, 78-95. [CrossRef]

293. Almutairi, Z.M. Effect of nano-silicon application on the expression of salt tolerance genes in germinating tomato ("Solanum lycopersicum" L.) seedlings under salt stress. Plant Omics 2016, 9, 106-114.

294. Zmeeva, O.; Daibova, E.; Proskurina, L.; Petrova, L.V.; Kolomiets, N.E.; Svetlichny, V.A.; Lapin, I.N.; Karakchieva, N.I. Effects of silicon dioxide nanoparticles on biological and physiological characteristics of Medicago sativa L. nothosubsp. varia (Martyn) in natural agroclimaticc of the subtaiga zone in western Siberia. Bionanoscience 2017, 7, 672-679. [CrossRef]

295. Slomberg, D.L.; Schoenfisch, M.H. Silica nanoparticle phytotoxicity to Arabidopsis thaliana. Environ. Sci. Technol. 2012, 46, 10247-10254. [PubMed]

296. Karimi, J.; Mohsenzadeh, S. Effects of silicon oxide nanoparticles on growth and physiology of wheat seedlings. Russ. J. Plant Physiol. 2016, 63, 119-123. [CrossRef]

297. Silva, G.H.; Monteiro, R.T.R. Toxicity assessment of silica nanoparticles on Allium cepa. Ecotoxicol. Environ. Contam. 2017, 12, 25-31. [CrossRef]

298. Ruffini Castiglione, M.; Giorgetti, L.; Geri, C.; Cremonini, R. The effects of nano-TiO 2 on seed germination, development and mitosis of root tip cells of Vicia narbonensis L. and Zea mays L. J. Nanoparticle Res. 2011, 13, 2443-2449. [CrossRef]

299. Ruffini Castiglione, M.; Giorgetti, L.; Cremonini, R.; Bottega, S.; Spano, C. Impact of $\mathrm{TiO}_{2}$ nanoparticles on Vicia narbonensis L.: Potential toxicity effects. Protoplasma 2014, 251, 1471-1479. [CrossRef]

300. Ruffini Castiglione, M.; Giorgetti, L.; Becarelli, S.; Siracusa, G.; Lorenzi, R.; Di Gregorio, S. Polycyclic aromatic hydrocarboncontaminated soils: Bioaugmentation of autochthonous bacteria and toxicological assessment of the bioremediation process by means of Vicia faba L. Environ. Sci. Pollut. Res. Int. 2016, 23, 7930-7941. [CrossRef]

301. Ruffini Castiglione, M.; Giorgetti, L.; Bellani, L.; Muccifora, S.; Bottega, S.; Spano, C. Root responses to different types of TiO 2 nanoparticles and bulk counterpart in plant model system Vicia faba L. Environ. Exp. Bot. 2016, 130, 11-21. [CrossRef]

302. Kah, M.; Hofmann, T. Nanopesticide research: Current trends and future priorities. Environ. Int. 2014, 63, 224-235. [CrossRef]

303. Oukarroum, A.; Bras, S.; Perreault, F.; Popovic, R. Inhibitory effects of silver nanoparticles in two green algae, Chlorella vulgaris and Dunaliella tertiolecta. Ecotoxicol. Environ. Saf. 2012, 78, 80-85. [CrossRef]

304. Dash, A.; Singh, A.P.; Chaudhary, B.R.; Singh, S.K.; Dash, D. Effect of silver nanoparticles on growth of eukaryotic green algae. Nanomicro Lett. 2012, 4, 158-165. [CrossRef]

305. Bakand, S.; Hayes, A. Toxicological considerations, toxicity assessment, and risk management of inhaled nanoparticles. Int. J. Mol. Sci. 2016, 17, 929. [CrossRef]

306. Oberdörster, G.; Elder, A.; Rinderknecht, A. Nanoparticles and the brain: Cause for concern? J. Nanosci. Nanotechnol. 2009, 9 , 4996-5007. [CrossRef] [PubMed]

307. Haase, A.; Tentschert, J.; Jungnickel, H. Toxicity of silver nanoparticles in human macrophages: Uptake, intracellular distribution and cellular responses. J. Phys. Conf. Ser. 2011, 304, 012030. [CrossRef]

308. Baranowska-Wójcik, E.; Szwajgier, D.; Oleszczuk, P.; Winiarska-Mieczan, A. Effects of titanium dioxide nanoparticles exposure on human health-A review. Biol. Trace Elem. Res. 2020, 193, 118-129. [CrossRef] [PubMed]

309. Baek, M.; Kim, M.; Cho, H.; Lee, J.; Yu, J.; Chung, H.; Choi, S. Factors influencing the cytotoxicity of zinc oxide nanoparticles: Particle size and surface charge. J. Phys. Conf. Ser. 2011, 304, 012044. [CrossRef]

310. Zhang, L.; Tan, S.; Liu, Y.; Xie, H.; Luo, B.; Wang, J. In vitro inhibition of tumor growth by low-dose iron oxide nanoparticles activating macrophages. J. Biomater. Appl. 2019, 33, 935-945. [CrossRef] [PubMed]

311. Anna, M.; Oksana, V.; Jana, K. Effect of chemically and biologically synthesized Ag nanoparticles on the algae growth inhibition. AIP Conf. Proc. 2017, 1918, 020008. 